\title{
Chapter 2 \\ Paradiplomacy in India As Exemplified by the State of Gujarat
}

(Grzegorz Bywalec) 



\section{Grzegorz Bywalec}

University of Lodz

\subsection{Introduction}

The constitutions of federal countries impose the duty of conducting foreign policy on the central authorities. However, over the last few years it has been noticed that an increasing number of powers in this regard have been delegated to the constituent units of federations such as: states, provinces, regions, cantons, federal states (Länder) etc. This trend is also noticeable in India. Sometimes it results from the intentionally implemented policy of the federal authorities, in other instances it constitutes incidental activity of the authorities of selected constituent units of the federation and at times the federal authorities are not able to conduct foreign policy not taking into account the opinion of regional governments especially as regards economy, ethnonationalist issues and ecology (Hazarika 2014, 35).

The issues concerning the activity of the constituent units of the Indian Federation (states) in the international arena have neither been thoroughly discussed nor described in the subject literature. The term "paradiplomacy" is not popular in India and it is rarely used. Even the highranking state officials who deal with the issues which remain within the scope of paradiplomacy cannot explain this term and do not associate their occupation with the foreign policy of the country or diplomacy'. Only in the last few years, since Narendra Modi became the Prime Minister of the federal government (26 May 2014), more attention has been focused on the issues connected with the activity of states in the international arena, both in the academic milieu as well as in the economic and political circles. It is connected with the fact that one of the priorities of the new government centres on the federalisation of economic development. One of the key

1 This observation is resultant from the interviews carried out by the author in July 2016 with the officials in the state of Gujarat who are employed at the institutions in charge of, inter alia, conducting activity in the international arena, i.e. primarily in the Industrial Extension Bureau (iNDEXb) and the Tourism Corporation of Gujarat Ltd (TCGL). 
elements of the aforementioned federalisation consists in intensifying the international activity carried out by the state authorities predominantly in the field of economy. Professor Shantanu Chakrabarti from the University of Calcutta claims that in most cases paradiplomacy in India comes down to attracting direct foreign investment and other business connections (Shantanu Chakrabarti 2015, pers. comm.). One of the new and significant objectives of the foreign policy conducted by Narendra Modi's government is to intensify the international activity of states ${ }^{2}$. Up till now this kind of activity has neither been thoroughly codified nor constituted a part of the policy pursued by the federal government. Certainly, there have been cases when Chief Ministers have made incidental attempts at establishing international contacts predominantly with regard to encouraging foreign businessmen to invest in their states. These kinds of undertakings have not been common, though. Additionally, they have not been induced or coordinated by the federal government. The situation has been slightly different in the border states which have generally cooperated with their counterparts on the other side of the border, whereby the said cooperation has primarily focused on the issues related to culture, tourism and less often to economy (e.g. the problem of river training or organisation of communication routes) as well as to interpersonal relations (e.g. of a family, tribal or religious nature). The coastal states have acted alike.

As regards the institutional organisation of the country, the Indian foreign policy is founded on two pillars. One of them, being at the same time crucial, is the official policy pursued by the federal government which, according to the Constitution of India, is in charge of implementing thereof. The other pillar, which is based on the decentralised activity carried out by the second tier of the Indian administration, is the regional pillar. It has emerged only in the last few years but it is certainly going to play an increasing role in the Indian reality.

This study constitutes an attempt at describing and evaluating the experience of India with regard to the participation of Indian states in the foreign policy of the country along with indicating the determinants of this process. Certain barriers have also been identified in the study which hinder the decentralisation of foreign policy, or at least of some of its elements, and often make it impossible. The analysis covers the period after the year 1991, which is the time when India implemented the so

2 See P.M. Modi's Foreign Policy Objectives, VISION IAS, http://ajayvision.com/ beta/sites/all/themes/momentum/files/CA_Important_Issues/PM\%20Modi's\%20 Foreign\%20Policy\%20Objectives.pdf (accessed 19.06.2016). 
called New Economic Policy, which consisted in the liberalisation and deregulation of the economy and the country. In the wake of the introduction of this policy India opened to the world and thus became involved in the process of globalisation. As regards the system of government, it underwent a significant change in the form of decentralisation. In 1992 two amendments to the Constitution were passed ( $73^{\text {rd }}$ and $74^{\text {th }}$ ), which obligatorily established the third fully democratic local tier of public administration thus initiating the most extensive decentralisation in the history of mankind 3 .

Due to a highly complex character of the Indian reality in the cultural, political and economic sense, it will be difficult even in the future, when the independent international activity carried out by states is likely to become one of the pillars of development, as the statements made by the central government indicate, to formulate a model of such an activity which would be adequate for the whole country. International policy pursued by states will differ in the case of the border states, e.g. West Bengal, which in cultural terms constitutes a part of Bengal (along with Bangladesh), from that conducted by the impoverished states situated in the middle of the country (without a coastline), and it will still be different in affluent states where strong nationalist movements prevail (with regard to the regional identity) such as Maharashtra, Punjab or Tamil Nadu.

Even though certain models of paradiplomatic activities have been worked out in different national and political contexts (see, for instance, relatively recent Aleksander Kuznetsov's (2015) model referenced in the introductory chapter of this volume), in the case of India they remain inadequate and practically inapplicable. Given the complexity of Indian culture and politics, implementation of methodological scheme offered by Kuznetsov is virtually impossible. In India systematic examination of paradiplomatic activities based on the interviews with state officials is rather complicated. It is so for at least two main reasons. First, they often do not know the concept of paradiplomacy and are confused with it. Second, they are not willing to share their experiences with researchers due to the potential discrepancies between priorities on the central and regional political agendas. Hence, conducting interviews according to the procedures indicated in Kuznetsov's model (2015) remain pointless and

3 The issues concerning the local tier in India will not be elaborated on in the study due to the fact that the impact exerted by the local units on the foreign policy of the country is, apart from a few exceptions, insignificant and hard to grasp. 
does not bring about expected results. The paradiplomatic processes in India do not follow any particular logic, are often chaotic and incidental. If they occur at all, they are to a large extent dependent on the people who wield power in the states as well as their political interests, ambitions and features of character. These are the reasons which Rodrigo Tavares $(2016,43)$ points to when explaining the increasing involvement of West Bengal (governed by Mamata Banerjee) and Gujarat (under the rule of Narendra Modi) in the international arena. Thus it is difficult to formulate the paradiplomacy model in particular states, which makes indicating common features of this process on the nationwide scale even harder.

This chapter has been divided into three parts. In the first subchapter the government system and the territorial structure of India will be characterised. It is impossible to understand the Indian paradiplomacy without focusing on the constitutional mechanisms which regulate the government system and the territorial structure in the country. India is the country with a federal structure, however its specific character makes the country far different from the classical understanding of a federal country. The subject matter of federalism is probably the most commonly described and discussed problem in the social sciences in the Indian Subcontinent, which points to the significance that theoreticians and practitioners of governing attach to the form of government system in the country. The second subchapter constitutes an attempt at characterising paradiplomacy in India on the nationwide scale, presenting its determinants, pointing out the directions in which it could develop both in the time and spatial perspective. The first section of this subchapter is devoted to presenting the institutional environment of the international activity conducted by the regions, which predominantly consists in indicating legal possibilities as regards the actions undertaken by states in the international context. The second section presents particular instances of paradiplomatic activity in various parts of the country. The third section of this subchapter focuses on the individual characteristics of the border states which are the regions which predominantly affect the policy conducted by the central government targeted at the countries or regions of India's immediate neighbourhood. On the basis of these states it is also possible to observe the impact they exert on other, apart from economic ones, directions of the foreign policy of India. Since the literature on the subject is still scarce it is very difficult, at the current stage of research in this field, to fully grasp the essence of this problem in India and to find the common denominator for the whole country. 
The third subchapter is essentially a case study of paradiplomacy in India as exemplified by the state which is one of the fastest developing regions after the year 2000 - the Western India state of Gujarat. For many years now the said state has founded its model of development on the paradiplomatic activity. The experience of Gujarat in this regard may be considered trailblazing on the nationwide scale.

In accordance with the Regional Internalisation Index (see Annex 4), which was developed especially for the purpose of this study, depending on the research methods applied, the most internationalised state in India is Maharashtra (with regard to the value of the index per capita as well as with regard to the overall index). The State of Gujarat occupies the third and the forth place in the ranking, respectively. However, the State of Gujarat was deliberately selected as the subject of research. Nowhere else in India is internationalisation dependent to such a large extent on the actions taken by the regional government on the international arena, which makes Gujarat a perfect example for the purpose of analysing paradigmatic activity.

The choice of Gujarat as the subject of more detailed analysis is resultant from the fact that Narendra Modi ${ }^{4}$, the long-standing Chief Minister of the state and an eager proponent of paradiplomacy applied as a development tool, in May 2014 took office as the Prime Minister of the federal government and declared that he would try to foster the best possibilities for the regions to carry out independent activities in the international arena. Therefore, it may be presumed that in the near future the Gujarat's model, which had been implemented for thirteen years in the state by Narendra Modi, will become a political beacon for other states and possibly a model example of paradiplomacy in India. The subchapter will present a few examples of the activity carried out by the state authorities in the international arena, which will be analysed predominantly in the scope of economic and business relations, since in these two fields state governments are the most effective. The time span covers the years when Narendra Modi, an earnest proponent of regional diplomacy, was in office as the Chief Minister of Gujarat (2001-2014). The subsequent period (after the year 2014), when Narendra Modi took office as the Prime Minister of the federal government, would be hard to

4 Narendra Modi's private life and political career have been covered by, among others, Verma (2015), Vashisht and Saxena (2014), Pankaj (2015), Nag (2014), Sanghavi (2015), Mohan (2015), Kuman (2016), Kamath and Randeri (2013), Fernandes (2014). 
describe from today's perspective (2017) as the period of governing is too short. However, an attempt will be made to indicate and evaluate the first paradiplomatic activities declared and carried out by the newly-elected authorities.

\subsection{The territorial organisation and the system of government in India as the main determinant of paradiplomacy in India}

\subsubsection{The territorial structure in India}

On 15 August 1947 India ceased to be a colony and became a dominion within the framework of the British Commonwealth of Nations (as of 1949 - the Commonwealth of Nations). India gained the status of a sovereign country on 26 January 1950 - on the day when the Constitution ${ }^{5}$ entered into force. Since that day India has been a parliamentary republic with a federal structure. Never before had a country bearing the name India existed. The term "India" had had only a geographical meaning. Thus a new, enormous country appeared on the map of the world.

The Dominion of India created in 1947 comprised the so called British India - the colony subjugated to the direct British rule as well as approximately 560 princely states. The remaining part of British India and several dozen princely states became a part of Pakistan inhabited predominantly by Muslims who declared independence on 14 August 1947.

The system of government in India is determined by the Constitution adopted on 26 November 1949. It consists of the Preamble, the main body and 12 Schedules. It has 395 Articles and some of them comprise a few sections. The constitution may be primarily modified by amendments. As at June 2016 there were 101 of them. It is the longest constitution in the world which very elaborately regulates the structure, functioning and powers of the main institutions of the Republic of India, including the territorial structure of the country. The detailed character of the constitutional regulations results, first and foremost, from the specificity of the Indian society, which consists in its vast ethnic, language and religious diversity which is incomparable to that in any other country

5 When the Constitution of India is referred to, unless specified otherwise, the following source is meant: Bakshi. Parvinrai Mulwantrai. 2015. The Constitution of India. Gurgaon: LexisNexis. 
in the world as well as social stratification. In order to create one society and one sovereign entity from such a conglomerate of people accurate regulations are required, especially at the highest nationwide level.

India is a federal republic - the Union of States. The underlying ideological message of the Indian system of government is included in the Preamble to the Constitution which in its initial version stated that India is "a sovereign, democratic republic". In 1976 by virtue of the 42 nd amendment to the Constitution two words were added "secular" and "socialist". India is a democratic country modelled on the Western pattern and due to the number of inhabitants it is often referred to as "the largest democracy in the world".

The issues related to the territorial organisation of India, and particularly determining the number and boundaries of states constituted the most difficult political problems in the first decades of independence. They have always aroused many controversies which have recurrently led to social conflicts, often entailing bloodshed. Figure 2.1 presents the chart outlining the administrative structure in India.

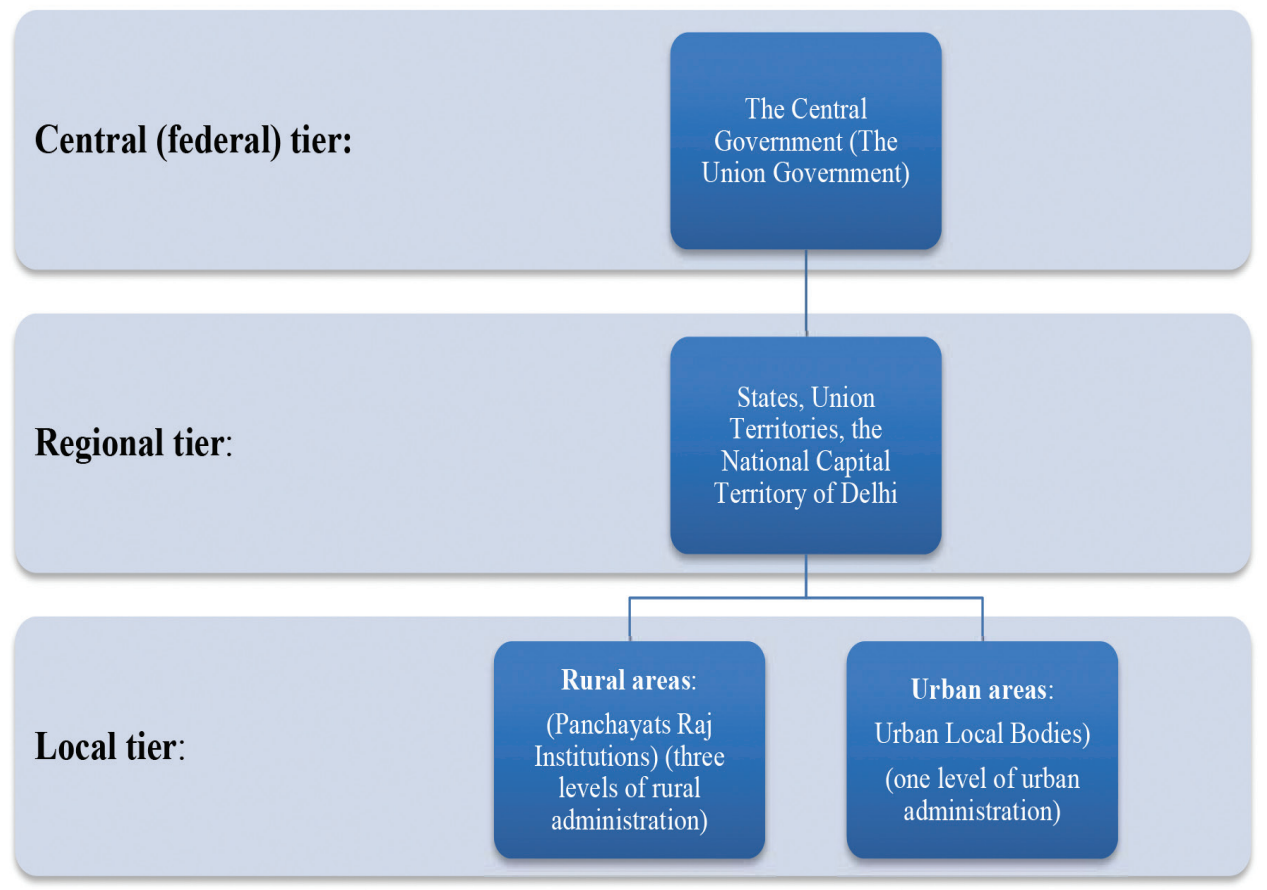

Figure 2.1. Chart outlining the administrative structure in India Source: Compiled by the author of the study on the basis of Bakshi (2015). 
The initial territorial structure in India established in 1950 was based on the division of the country according to the boundaries of British provinces and princely states. 27 states and the union territory were distinguished. However, states varied in terms of their status: A (the largest 9 states), B (8 former princely states and groups of princely states), C (10 so called former chief commissioners' provinces and some princely states), D (the Union Territory of Andaman and Nicobar Islands).

Yet, the aforementioned division proved inadequate to the requirements of the new reality and after only a few years in 1956 significant changes to the administrative structure in India were introduced on the basis of the $7^{\text {th }}$ Amendment to the Constitution (The States Reorganization Act 1956). By virtue of the said Act, existing 27 states which varied in status were superseded by 14 states with an equal status and 6 centrally governed union territories. These were the following states: Andhra Pradesh, Assam, Bihar, Bombay, Jammu and Kashmir, Kerala, Madhya Pradesh, Madras (as of 1968 referred to as Tamil Nadu), Mysore, Orissa, Punjab, Rajasthan, Uttar Pradesh and West Bengal. The status of union territories was granted to: the Andaman and Nicobar Islands, Delhi, Himachal, the Laccadive, Minicoy and Amindivi Islands as well as Manipur and Tripura.

Such a solution, as it was proved in the course of time, did not guarantee the territorial stability of the country. In the subsequent years, as a result of strong grassroots movements of an ethnic and religious character, new states were created and this process has probably not been completed yet. In 1960 Bombay, which was formed by combining Maharashtra and Gujarat, was again split into two separate states of Maharashtra and Gujarat. In 1963 the state of Nagaland was created from a part of Assam. In 1966 Punjab was split into two states - Haryana (inhabited predominantly by the Hindu population) and Punjab (inhabited predominantly by the Sikh population). In 1969 Meghalaya was formed from a part of Assam, which was granted the status of a state in 1971. In 1971 the union territory of Himachal was converted into a state, and in 1972 the territories of Manipur and Tripura underwent the same process. In 1973 the state of Mysore was converted into Karnataka. In 1975 Sikkim was formed and in 1987 Mizoram, Arunachal and Goa became states. In the year 2000 three additional states were carved out: Uttaranchal (as of 2007 referred to as Uttarkhand), Jharkhand and Chhattisgarh. In 2014 a new state of Telangana was created from a part of Andhra Pradesh. Currently (2017) India comprises 29 states, 6 union 
territories and the National Capital Territory of Delhi. Union territories play an insignificant role in the public life of India. They include: small islands in the Bay of Bengal and in the Arabian Sea as well as the coastal enclaves which are former colonies of France and Portugal. The National Capital Territory of Delhi situated on the border of Haryana and Uttar Pradesh is an unusual administrative entity which was formed in 1991. It comprises the city of Delhi and a few neighbouring districts.

These administrative changes have over almost 70 years led to vast diversity among India's states in terms of area and population. Rajasthan, Maharashtra and Madhya Pradesh are the largest states - each with an area of more than 300 thousand $\mathrm{km}^{2}$. Whereas the smallest state is Goa totalling only 3.7 thousand $\mathrm{km}^{2}$ in area. It is 92 times smaller than the largest state - Rajasthan. Demographic diversity is even greater. Uttar Pradesh is the most populous state in India, since it is inhabited by over 210 million people, whereas Sikkim, with around 600 thousand inhabitants, is the least populated. The aforementioned differences exert a great impact on the functioning of the whole country. Despite having formally an equal status, particular states play strikingly different roles in the real political, economic and sociocultural life in India.

\subsubsection{The organisation and powers vested in the authorities at the central and state level}

The organisation of the legislative and executive power in India is governed directly by the Constitution. Its primary entities at the central (federal) level encompass: the Parliament, the President, and the Union Government (the Council of Ministers). The middle tier (regional level) comprises: states, union territories and, as of 1991, the National Capital Territory of Delhi. Figure 2.2 presents the organisation structure of authority at both tiers.

The legislative power in India is vested in the Parliament which consists of the President and two chambers: the House of the People (the Lok Sabha) and the Council of States (the Rajya Sabha). The House of the People consists of no more than 552 members, 530 out of whom are elected in direct elections held in states and up to 20 Members are elected in union territories. Furthermore, the President of the Republic of India may co-opt no more than two additional members who are the representatives of the so called Anglo-Indian community if he comes to the conclusion that it is not adequately represented in the Parliament. The 
$50 \vdots$ Grzegorz Bywalec

\section{LEGISLATIVE POWER}

Federal tier

\section{PARLIMENT OF INDIA}

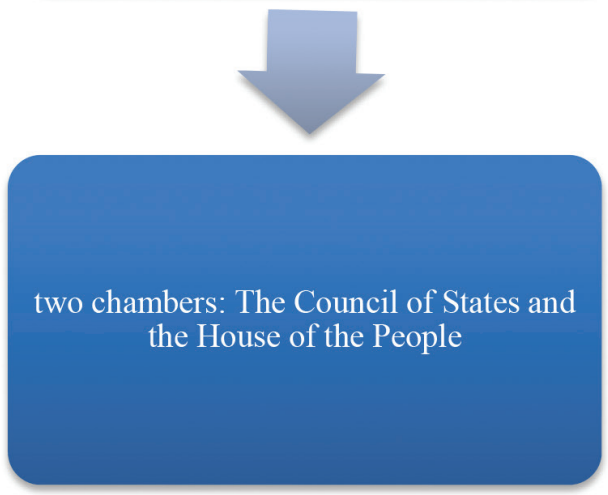

State tier

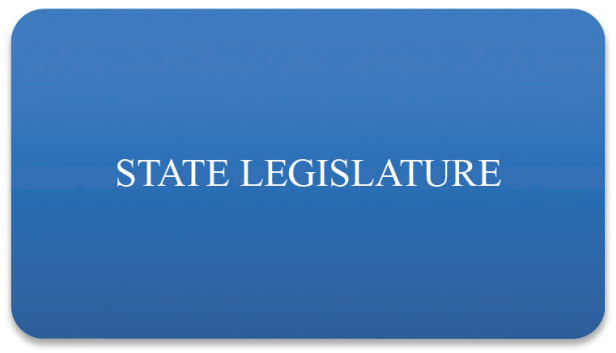

In the states Andhra Pradesh, Assam, Bihar, Jammu/Kashmir, Karnataka, Maharashtra, Telangana, Uttar Pradesh a bicameral system applies - the Legislative Assembly and the Legislative Council

In the other states a unicameral system applies - the Legislative Assembly.

\section{EXECUTIVE POWER}

Federal tier

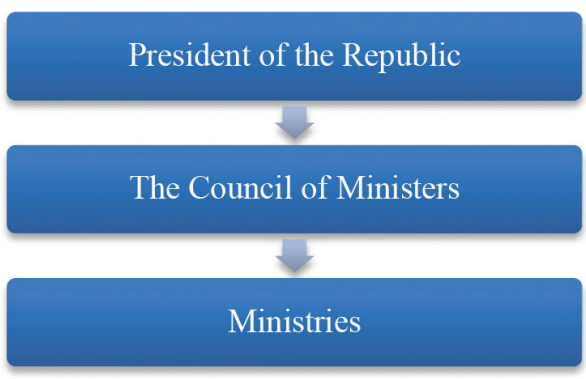

State tier

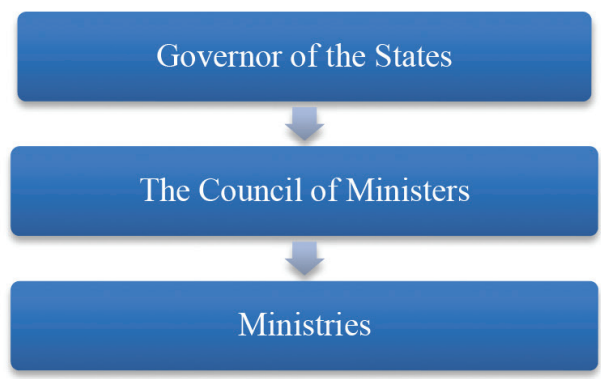

Figure 2.2. The organisation of government at the federal tier and the state tier in India Source: Compiled by the author of the study on the basis of Bakshi (2015). 
term of office of the House of the People lasts five years but the chamber may be dissolved before the expiry of the term by virtue of the decision of the President.

The upper house referred to as the Council of States consists of a maximum of 250 members, 12 of whom are appointed by the President of the Republic (in appreciation for their contribution into arts, literature, science and public activity) and no more than 238 members are elected by the Legislative Assemblies of the states and by union territories. The Council of States is not subject to dissolution, however every two years one third of its members are replaced by newly-elected ones.

The President of the Republic is the highest organ of the executive power, i.e. Head of State, who is elected for the term of five years by an electoral college consisting of the members of both houses of the Parliament as well as the members of the State Legislative Assemblies. The Vice-President, who is elected by the members of both houses of the Parliament, is the second-highest ranked government official in India. The Vice-President plays an ex officio function of the Chairman of the Council of States and his or her term of office also lasts 5 years.

The Council of Ministers is a lower organ of the federal executive power. It is appointed to assist the President in carrying out the constitutional functions. The Prime Minister is appointed by the President, whereas other Ministers are also nominated by the President, yet upon the recommendation of the Prime Minister. The Council of Ministers is as a collective accountable to the House of the People. In general, the people nominated to the office of the Prime Minister of the federal government are indicated by the parties which have won the most seats in the House of the People.

At the state level the legislative power is executed by the Governor of the State as well as state legislative bodies which in the following states: Andhra Pradesh, Bihar, Jammu/Kashmir, Karnataka, Maharashtra, Telangana, Uttar Pradesh consist of two chambers, namely the Legislative Assembly and the Legislative Council, whereas in other states legislature is unicameral and encompasses only the Legislative Assembly. The electoral procedure with regard to the collective legislative bodies of states is complex and differs in the case of bicameral and unicameral states. As regards the former, a certain number of deputies are chosen in elections and a proportion of them are appointed by the Governor of the State. As for the latter, the members of state assembly are chosen in direct elections.

Apart from being the member of the legislative authority, the Governor of the State exercises primarily the executive power, as he or she is the 
highest organ of this kind of power at the state level. The Governor of the State executes the said power by means of the state Council of Ministers. He or she is appointed by the President of the Republic for the term of five years. The President is entitled to dismiss the Governor at any time if he does not approve of his or her performance. Moreover, the President of the Republic can give direct instructions to the Governor. In the light of the aforementioned powers vested in the President of the Republic of India, the status held by states is not unambiguous. As befits a federal country, they enjoy considerable independence by virtue of the constitutional provisions, yet the fact that the Governor can any time be removed from office by the President of the Republic practically limits the said independence to a large extent ${ }^{6}$.

There is the Council of Ministers formed also at the state level. It is headed by the Chief Minister and, in a similar manner as it is in the case of the federal government, it assists and advises the Governor in his or her carrying out of the executive power. The Chief Minister is appointed by the Governor of the State. Ministers are also appointed by the Governor, yet on a proposal from the Prime Minister. The state Council of Ministers is as a collective accountable to the Legislative Assembly of the state.

Apart from states, there exist also the so called union territories. These are very small administrative units which are ruled directly by the federal authorities. The President of the Republic governs union territories by means of an administrator who is elected by him. By virtue of the Parliament's decision, union territories may be provided with the Legislature and the Council of Ministers or with only one of these institutions. In 1991 under the 69th Amendment to the Constitution, the National Capital Territory of Delhi was created which, in a similar manner as union territories, reports directly to the Central Government, yet it has a well-developed self-government.

The division of powers between the central and state authorities in not always separable. Some of the powers lie within the competence of both the central government and the state government. A detailed scope of powers vested in the central and state authorities is presented in the so called allocation of powers lists, which constitute the Seventh Schedule in the Constitution of India and encompass the Union List, the

6 Such a solution results, first and foremost, from the concern about the integrity of the country. Far-reaching independence could lead to the disintegration of the country, given specific Indian ethnic and religious conditions. 
State List and the Concurrent List' 7 . The first list enumerates the powers allotted to the central bodies, the second one those vested in the state bodies, whereas the third presents the powers which can be exercised both at the central and the state tier. According to the Union List, the primary tasks of the central (federal) government encompass: national defence, federal administration of justice, federal legislation, diplomacy, organisation of economic and social statistics, studies and research of particular importance, national highways, railways, ports, and airports, environment protection or industry and trade regulation.

The majority of public tasks are carried out by the state authorities in accordance with the State List. The powers allotted to state governments first and foremost encompass: police, civil defence, state administration of justice, secondary and higher education, education of adults, social welfare, healthcare and hospital care, public housing, regional and town planning, state roads and selected interregional roads, environment protection and consumer protection, culture (theatres, museums, libraries, sport and tourism), interregional public utilities (gas, water, electricity) as well as selected agricultural issues. States share some of the aforementioned tasks with local self-governments.

At the local level (lower than the state level) there are 1-3 tier local selfgovernments, which was presented in Figure 2.1. They were established in the years 1992-1993 pursuant to the $73^{\text {rd }}$ and the $74^{\text {th }}$ Amendment to the Constitution 8 .

\subsection{The international activity undertaken by states in India - nationwide experience}

\subsubsection{The institutional basis of paradiplomacy in India}

Despite 70 years of existence of independent India, so far no uniform and clear system of regulations has been worked out, which would concern the international activity of the constituent units of the second tier of the structure of the Union of India, i.e. states. Some researchers overtly

7 The powers of states with regard to paradiplomatic activity will be elaborated on hereinafter.

8 The powers of local self-governments, as it was pointed out in the first footnote, will not be discussed in this study as their impact on the international activity of states is negligible and hard to track. 
point to a lack of direct legal regulation of the activities of states in the international arena. It is possible to refer indirectly to selected sections of the Constitution of the Republic of India, and in particular to the aforementioned Union List and State List (Obja Borah Hazarika 2016, pers. comm.). Such a status quo is resultant from the following factors:

1. Vast cultural, religious, economic or geographical diversity among states.

2. Different and often conflicting interests between individual states but also, in many cases, between particular states and the federal government.

3. Involvement of selected states (predominantly border states) in the issues for which the central authorities should be formally responsible, yet de facto considerable responsibility is exercised by the regional authorities (the problem of refugees, cross-border trade, smuggling etc.).

4. The centralised manner of governing the country, which on the one hand, constitutes the legacy of the political and economic model of the country which was implemented in the first four decades of its existence (until the 1980s), and on the other hand, results from the character of the highly diverse Indian Federation. Excessive decentralisation with regard to international activity could contribute to undermining the integrity of the country, which in the long run and under particular circumstances could lead to the break-up of the Union of India.

5. The dynamically changing political and economic situation (numerous social conflicts - for example of an ethnic, religious and economic character), which is not conducive to legislating stable and thus hardly flexible provisions concerning the analysed subject matter.

6. A low level of awareness and a lack of experience among the Indian political and academic elites (acting in the advisory capacity) as regards the possibilities of stimulating states to taking actions in the international arena and thus giving them an additional development incentive.

7. As it has been mentioned before, the shape of the supreme legal act in India, i.e. the Constitution in which it is possible to find such regulations in an indirect manner, provided that the constitutional provisions are adequately interpreted.

8 A relatively small scale of the activity of states in the international arena undertaken so far. It was Narendra Modi, the current Prime Minister of the country and in 2013 a candidate for this office representing the Bharatiya Janata Party, who, during the electoral campaign, first indicated the need for redefining foreign policy with regard to economic issues and 
for conferring greater powers on states when it comes to promoting trade and investments and thus attracting foreign capital (Ratna 2013).

It is likely that some attempts will be made, possibly in the nearest future, at creating a legal framework directly regulating the involvement of the state authorities in the international arena. It will not be easy, though, due to, inter alia, the above mentioned determinants. In the first stage these attempts will probably be limited to very general provisions which will be interpreted, further developed and set out in detail by the legislatures of the interested states or even some organs of the local tier (e.g. districts). It is possible to point out at least two factors which may contribute to state governments playing an increasing role in the foreign policy of India. They are as follows: a growing significance of coalitions in governing the country (including in particular regional parties) and progressive liberalisation and deregulation of the economy in the wake of the 1991-1992 reforms 9 .

However, the lack of unambiguous provisions does not mean that the international activity of states is carried out in the institutional and legal void. Legal regulations and institutional solutions are searched for in an indirect manner, as it has been mentioned before, in various legal acts issued by Ministries, legislation enacted by particular states etc. Yet, the interpretation of the relevant excerpts of the Constitution plays the most crucial role. The said interpretation may not consist in explicit reading of concrete sections but be implied by "the spirit of the Constitution". Certain researchers dealing with the subject matter of paradiplomacy in the Indian context point to such an approach, although there are just a few of them.

Although the term "paradiplomacy" or "regional diplomacy" does not occur in the Constitution, it is possible to find in it certain regulation of the activities within the framework of which state governments can conduct independent activity beyond the borders of the country. More detailed provisions concerning the international activity of the regions can be found, as it has been mentioned above, in the decentralised legislation enacted by individual states and in other documents issued by regional governments, such as for example documents concerning regional policy with regard to industry, trade and tourism ${ }^{10}$.

\footnotetext{
9 These issues will be elaborated on hereinafter.

10 Further information will be presented in the subchapter devoted to Gujarat.
} 
When analysing the supreme legal act in India, it is possible to make general conclusions concerning legislation which is and/or may be applied with regard to the subject matter of paradiplomacy.

The Constitution of India entered into force on 26 January 1950 and is the longest supreme law in the world. It very elaborately regulates many dimensions of the Indian reality, many of which are the issues addressed by the majority of countries in legal acts which have a status of the statutes. Despite the federal character of the country, the Constitution of India treats the central authorities and the regional authorities in an asymmetric way, conferring on the former ones relatively vast powers in comparison to other federal countries ${ }^{11}$.

It is necessary to bear in mind, though, that the formation of the Indian federalism is still an ongoing process despite the lapse of 70 years. The Constitution was formulated under particular conditions when British India was split into India and Pakistan. A more detailed analysis of the discussion concerning the system of government dating back to the colonial period indicates that the "founding fathers" of independent India wanted the country to be unitary with certain elements of federalism. They were aware of numerous dangers which the federal character of the country brings about, in particular in the form of separatist trends sustained by certain administrative units. Therefore India is often referred to as a quasi-federal country.

The analysis conducted herein covers only those excerpts of the Constitution of India which will be useful in determining the actual and potential powers of states with regard to their activity in the international arena, i.e. the so called paradiplomacy.

The supreme law very elaborately regulates the division of powers between the central government and the regional and local authorities. However, the said division is highly asymmetric since more extensive powers are vested in the federal government than in the constituent units of the Indian Federation - states ${ }^{12}$.

The central government enjoys a more privileged position in many issues. As it has been mentioned before, the Seventh Schedule in the Constitution of India includes three lists of allotted powers: the Union List, the State List

11 Although India is by definition a federal country, the term "federalism" does not occur in the text of the Constitution.

12 As at 03.01.2017 the Republic of India is divided into 29 states and 7 union territories pursuant to the First Schedule in the Constitution of India. 
and the Concurrent List. They enumerate respectively 100, 61 and 52 items pursuant to which powers are conferred on the central government, the state authorities or may be shared by both the aforementioned tiers's .

When referring to the Concurrent List, it is worth stressing that in conflicting situations the central jurisdiction takes priority over the state one, whereas the issues which are not covered in the lists of allotted powers are automatically included in the competence of the federal (central) government. According to Article 248 of the Constitution of India, the central government is entitled to make law concerning any matters not enumerated in the Concurrent List and the State List (including the imposition of taxes). Additionally, the central government appoints the Governor of the State in each state, who supervises the functioning of state governments. The federal parliament has the power to change the boundaries of states and create new states. Under particular circumstances, the central government can also dismiss the state government replacing it with President's rule. Despite the noticeable asymmetry in powers vested in the central government and the state authorities, in respect of both legislative and executive power, the Constitution of India is sufficiently flexible to allow the possibility of delegating/creating powers between the federal and regional tier on a day-today basis ${ }^{14}$. As George Mathew (2006) aptly puts it: "The union is a framework of federal nation building wherein the autonomy of the constituent units is moderated circumstantially and in accordance with the changing imperatives of the "national" and larger 'public interests"”. It should also be emphasised that many provisions set forth in the Constitution are subject to detailed, legal analysis when particular cases take place.

According to the Constitution of India, foreign policy lies within the competence of the central tier. It is the federal government that conducts foreign policy, and the Ministry of External Affairs is the main institution

13 As for the Union List, it originally enumerated 97 powers. Certain items have been added to it and other deleted. However, for practical reasons the ordinal numbers have not been changed which means that for example item 32 is immediately followed by item 34 (item 33 has been repealed). Additional powers are included as for example item 92A, 92B, 92C. It is similar in the case of other lists. The State List initially encompassed 66 items and the Concurrent List 47 items. The lists of allotted powers will not be annexed to this study due to their length, little usefulness of quoting such detailed regulations (apart from certain exceptions) for the purpose of the analysis conducted in the study and, first and foremost, because of general accessibility to these data.

14 A detailed analysis of the legislative and executive powers vested in all or even one region of India would require an extensive legal analysis and a separate publication. It goes beyond the thematic scope of this study. 
responsible for its shape. Item ten of the Union List, which constitutes the Seventh Schedule in the Constitution of India and refers to the powers allotted to the central tier, explicitly stipulates as follows: "Foreign affairs; all matters which bring the Union into relations with any foreign country". The said item leaves no doubts as to which tier of power is in charge of the matters of an international character. It is also worth enumerating other items mentioned in the Union List which are directly connected with the international issues. They are as follows:

1. Diplomatic, consular and trade representation.

2. United Nations Organisation.

3. Participation in international conferences, associations and other bodies and implementing of decisions made thereat.

4. Entering into treaties and agreements with foreign countries and implementing of treaties, agreements and conventions with foreign countries.

5. War and peace.

6. Foreign jurisdiction.

7. Citizenship, naturalisation and aliens.

8. Extradition.

9. Admission into, and emigration and expulsion from, India; passports and visas.

10. Pilgrimages to places outside India.

11. Foreign Loans (Bakshi 2015, 408).

The central government is vested with the powers to declare war, establish diplomatic relations with countries and organisations, ratify international treaties and other treaties. It should be added that from the very beginning of the process of drafting the Constitution there were opinions against enabling the central government to conclude international agreements which would encroach upon the legislative competence, allocated to states pursuant to the State List, without securing their consent. However, these suggestions were rejected. The burden of conducting foreign policy rests unequivocally on the centre and the administrative units of the lower level have very limited scope for action ${ }^{15}$. Even in the situation when, theoretically speaking, most states object to a particular element of foreign

15 Prakash Nanda points out that in almost 70-year history of independent India there were periods when foreign policy was dominated by the heads of the government. He mentions such government leaders as Jawaharlal Nehru, Indira Gandhi, Rajiv Gandhi, Narashima Rao or Atal Behari Vajpayee. 
policy, the central government is not bound by the Constitution to take this objection into account (Matoo and Jacob 2009, 173). It does not mean that Indian states have no competence whatsoever to independently take actions in the international arena.

The State List encompasses, as it has been mentioned before, 100 items which denote the powers vested in the state authorities. Pursuant to Article 246, Clause 3 of the Constitution of India:

"Subject to clauses (1) and (2), Legislature of any State has exclusive power to make laws for such State or any part thereof with respect to any of the matters enumerated in List II in the Seventh Schedule (in this Constitution referred to as the 'State List')" (Bakshi 2015, 269). When enacting laws in accordance with the State List, state legislatures are bound by other constitutional provisions, i.e. they cannot infringe the so called "Fundamental Rights" (Khosla 2016, 52). Most issues enumerated in the State List regulate various domestic affairs in India. Approximately one third of the provisions set forth therein is directly or indirectly, depending on the interpretation, connected with the international relations of the Republic of India. It is worth stressing that most sectors which are significant as regards the liberalising processes of the economy are subject to state jurisdiction. The said sectors encompass: industrial infrastructure, energy, development, agriculture and irrigation and social sectors such as education and healthcare. The policy of economic liberalisation is formulated at the federal tier, but its implementation would not be possible without active involvement and assistance on the part of states. In this way states contribute to conducting foreign policy in the scope of economy (Jha 2014, 4).

The international activity of states comprises largely or exclusively their activity in the economic arena. Therefore, the set of provisions regulating the powers vested in state governments with regard to international economic activity should include the acts of law which concern the establishment and functioning of Special Economic Zones, which substantially facilitate the process of attracting foreign investment to states ${ }^{16}$. The Special Economic Zones Act was passed by the Indian Parliament and signed by the President in 2005 and together with the SEZ Rules has been effective since 10 February 2006. State governments play a vital role in the SEZ policy. They are not only

16 The first Special Economic Zone in India (and at the same time the first in whole Asia) was set up in 1965 in Kandla in the state of Gujarat. It was called Export Processing Zone (EPZ). Cf. History of SEZ, http://business.mapsofindia.com/sez/history-india. html (accessed 16.09.2915). 
entitled to set up Special Economic Zones but, as stipulated in statutory law, they are expected to promote export as well as ensure adequate infrastructure which is needed for their efficient functioning ${ }^{17}$. Without state guarantees confirming that they have infrastructural resources indispensable for the operation of the SEZ no permission will be granted to establish the zone and conduct economic activity within its framework. Additionally, state governments have their representatives in the Inter-Ministerial Committee on private SEZ who are consulted when a proposal for establishing the SEZ in a particular state is considered.

It is also necessary to distinguish a particular type of activities undertaken by the state authorities which, by their very nature, are not governed by any legislation and at the same time they, undoubtedly, constitute a form of paradiplomatic activity. These are predominantly promotional activities of a soft power nature which are not banned by the central jurisdiction and are not contrary to the interests of the Union. They encompass, among others, statements of the Chief Ministers in which they called on the Indian subjects who reside and work abroad to return to their home states, promotion of Bollywood, Tollywood, Kollywood, Mollywood, Sandalwood, Jollywood films and other films abroad by the governments of the interested states or requests directed to the Chief Ministers of the border states asking them to get involved in settling regional conflicts ${ }^{18}$. It is worth stressing that these Chief Ministers are closer to the local reality and often better suited to carry out this kind of activity than the authorities in Delhi.

\subsubsection{Paradiplomatic experience in India - an attempt at description and evaluation}

When reviewing the activity of India's entities of the middle tier-states - in the international arena, it is clearly noticeable that this activity is still poorly developed in relation to the great potential. The inhabitants of India

17 Special Economic Zones may be set up by the central government, state governments or their agencies as well as by public-law entities and private institutions. Cf. http:// sezindia.org/sez/faqs.html (accessed 16.09.2016).

18 The names of the film production hubs are inspired by the name of the home of the US film industry - Hollywood. Bollywood denotes film industry in Mumbai, Tollywood - films produced in the Telugu language, Kollywood - cinematography in the state of Tamil Nadu, Mollywood - films produced in the Malayalam language from Kerala, Sandalwood - films produced in the Kannada language from Karnataka and Jollywood - Assam film industry. 
- as participants of the biggest democratic parliamentary elections in the world - every four years elect their governments. An attempt to answer the question concerning electoral motivations of the people of India, both at the central and regional levels, is highly complicated and heterogeneous. Undoubtedly though, foreign policy has never been a decisive factor which influences an election result. Just a few times, during the conflicts with Pakistan, Bangladesh and the ethnic conflict between India and Sri Lanka, foreign policy issues exerted a more direct influence on electoral decisions both at the central and state levels. It is one of the reasons why state governments show a relatively slight interest in engaging in international matters (Staniland and Narang 2015, 206). Obviously the processes of international activity of the regional entities are in progress and major differences in advancement and pace in terms of both time and space can be observed. The issue of the activities of the constituent units of the Republic of India, i.e. states in the international arena still has not been discussed profoundly and in essence in this country. Scarce literature on the subject and little research done in this field make studies on the issue of paradiplomacy resemble groping in the dark, and thus they can be fraught with mistakes made by "the first explorers". Therefore, this study should be treated as an introduction to the subject matter of paradiplomacy on the Indian ground, forming a basis for further discussions and in-depth research. An additional obstacle in research carried out on this subject in India is the fact that, although some serious theoretical studies and terminology of paradiplomacy exist in the world literature, the phrase paradiplomacy is hardly known and rarely used in India. Even state officials who deal with the matters connected with paradiplomacy are not able to decipher the term and can by no means associate their work with foreign policy of the country or diplomacy.

It is difficult to generalise with regard to the influence of particular component entities of the federation (states) on the foreign policy of the Republic of India, which results from the nature of the Indian Federation. It is inextricably linked to great differences in economic, political or cultural arenas within the country. That is the reason why none of the Indian states can be considered representative of all India and thus transposing the experiences of any particular region to other entities makes no sense. It is also impossible, for the same reasons, to create a pattern (model) of paradiplomacy in the Indian states.

Paradiplomatic processes in India, as it has already been observed, still do not have their objective logic, are often chaotic and incidental, 
and are not coordinated by the central government, and if they occur at all they depend, to a large extent, on the people wielding power in states, their political interests, ambitions and personal characteristics.

Although it is impossible to precisely quantify the activity of Indian states in the international arena, it is clearly noticeable that the phenomenon mostly concerns economy. Only the governments of the border states occasionally engage to a greater extent in matters other than those of the economic nature. It results predominantly from the nature of the phenomenon itself and constitutes a part of the world trend. The decentralisation of the political aspect of the foreign policy is much more difficult, whereas economic issues can be successfully, for the most part, entrusted to the states, thus partly making their economic prosperity dependent on their own policy in the international arena. In the case of India, it mostly consists in promoting the economic potential of the region, which is followed by attracting foreign investors. It is a widely exposed priority of the central and state authorities (in contrast to China which slowly transforms from a beneficiary to a supplier of investment). The formation of India Trade Promotion Organisation (ITPO) by the central government in the early 1990s can be considered the vanguard of economic paradiplomacy, the organisation encouraged establishing analogical units at the state level. Therefore, paradiplomacy in India comprises primarily attracting direct foreign investment by states and other business relations across borders. The problems connected with quantification and consequently with efficiency evaluation of the paradiplomatic activities result also from the fact that it is often not possible to separate the activities aimed at foreign recipients from those aimed at finding favour with domestic institutions and citizens. Big international events promoting Indian regions make local (Indian) businessmen ${ }^{19}$ invest there more willingly as well.

When reviewing the process of development of paradiplomacy in India, it is possible to distinguish three time periods, each characterised by a particular level of international activity carried out by states. They include:

1. The years 1947-1991 - the era of high centralisation of political and economic life, featuring precise economic plans, the policy of controlling practically all aspects of economic life, a high level of bureaucracy, state

19 A good example is building by TATA MOTORS a NANO car manufacturing plant in 2008 in Sanand, 30 kilometres from Ahmedabad, in the state of Gujarat, Initially the plant was to be built in the state of West Bengal but a wave of protests discouraged the investor and finally the plant was relocated to Gujarat. 
controlled economic policy and practical cut-off of the Indian economy from the global market (Bywalec 2015, 100). It is hardly possible to talk about involving states in foreign policy during this period and to observe any distinct tendencies with regard to the analysed matter. That is the reason why this stage is completely excluded from research and scientific reflection in this study 20 .

2. The years 1991-2014, which cover the period from the introduction of a package of reforms in India, concerning mostly the economy, until Narendra Modi's taking office as the Prime Minister of the federal government (26.5.2014). Modi is the former long-standing Chief Minister of the Western India state of Gujarat (in office for 13 years). The general conclusions presented in this study concern mostly this period, which marks the beginning of the formation of the policy of international activity of states and at the same time, indirectly, their becoming a part of the foreign policy of the country.

3. The period after the year 2014, which is the time when Narendra Modi took office as the Prime Minister of the federal government and declared that the paradiplomatic activity of states constitutes a direction affirmed by the federal government which will become one of the new priorities of the foreign policy of India. He also stated that he is going to promote such a model of economic development of India where the development of states becomes the driving force ${ }^{21}$. It means that Narendra

20 However, some opinions have been put forward that during the turn of the 1980s and 1990s state governments were not completely out of the foreign policy making processes. In 1987, during the war in Sri Lanka, when Rajiv Gandhi's government decided to air drop food in Jaffna in the north of Sri Lanka, the Chief Minister of Tamil Nadu, MG Ramachandrana was summoned to Delhi for consultations. Deve Gowda's government did the same while signing the Farakka Treaty with Bangladesh (a treaty concerning the division of the Ganges waters between Bangladesh and India) when consultations with the Chief Minister of West Bengal, Jyoti Basu were undertaken. At that time states played only an advisory role, whereas at present states try to dictate to the central government the directions of the foreign policy in order to correlate them with their internal interests (Nanda, 3-4).

21 The election manifesto of the winning party BJP from 2014 reads, among others, as follows: "We will place Centre-State relations on an even keel through the process of consultation and strive for harmonious Centre-State relations", "Our Government will be an enabler and facilitator in the rapid progress of states. We will evolve a model of national development, which is driven by the states", "Team India shall not be limited to the Prime Minister led team sitting in Delhi, but will also include Chief Ministers and other functionaries as equal partners" (Election Manifesto 2014). These promises can be treated as a prelude to an increase in the importance of the state authorities in the development policy of India (see BJP Manifesto 2014). 
Modi is going to transpose his experience from the Gujarat period to the central level and at the same time to encourage states to increase their own activity in the international arena. It can be expected that the process of the international activity of the states will at last gather momentum in India and that it will be treated with due importance. It may also be presumed that the said process will be subject to scrutiny on the part of a large group of scientists, journalists and commentators. Gaining power in 2014 by the BJP party with the Prime Minister Narendra Modi as the head of the government may mark the beginning of a new era in the sphere of relations between the centre and the states in India and at the same time a new stage in the development of the international activity of the states. In October 2013, in Chennai, Modi criticized the previous policy of the central government in the following way: "India is not just Delhi. The foreign policy should be decided by the people and not by some politicians sitting in Delhi" (Shekhar 2014)22.

The only period in the history of independent India which may become the subject of substantive analysis in terms of paradiplomacy spans from the year 1991 to the moment of Narendra Modi's taking power in 2014. During that time certain states became more active on the international ground, albeit with a different result and intensity, and thus the process of federalisation of the Indian foreign policy commenced. The reason for that state of affairs may be found in two parallel processes: the increasing importance of political coalitions in ruling the country and progressing liberalisation of the Indian economy. Since 1989 none of the main political parties has been able to gain absolute majority in the Lok Sabha. That is why since 1989 India has been ruled either by minority or coalition governments ${ }^{23}$. Due to the coalition policy, regional parties - being a member of the coalition in the federal government - can influence the foreign policy of the Union of India in practice and try to

22 Narendra Modi's declarations concerning the increase in the states' involvement in the foreign policy are not accepted without any criticism in India. There are comments that it is an example of a short-sighted and obsequious policy towards the regional parties and their leaders which does not reflect long term interests of the entire Union of India. That is the reason why critics are against the interference of the Chief Minister of West Bengal, Mamata Banerjee in the conflict with Bangladesh about the Teesta River or the influence exerted on the central government by the Chief Minister of Tamil Nandu, J. Jayalalithaa (who died on 5.12.2016) with regard to the foreign policy towards Sri Lanka, in order to secure safety for Tamils who live there.

23 After the 1989 elections, 27 regional parties gained seats in the parliament, and two years later (in 1991) the number of such parties increased to 43 (Matoo and Jacob 2009, 175). 
shape it in accordance with the interest of the states of their origin ${ }^{24}$. Prakash Chandra Jha from Amity University Rajasthan even claims that regional parties do not focus only on the regional issues but become actively involved in the decision making process with regard to all national matters within the foreign policy. To confirm his words he quotes one of the analysts of the foreign policy of India: "... power is flowing away from Delhi to state capitals, where some strong men and women are ruling. India's external partners tend to see this with much greater clarity than the domestic observers ... If Mamata has the last word on India's policy towards foreign direct investment in the retail sector, why won't outsiders go to Kolkata? If Gujarat and Bihar are places where you can get things done, aren't the Chinese communist leaders smart enough to woo the Chief Ministers of the two states?" (Jha 2014, 5). Thus it can be assumed that the year 1989 was the beginning of federalisation of the Indian political system, understood as the increased role played by state governments in the central policy. From that moment on, no Prime Minister could dictate to the states who was to become the Chief Minister, as it was done during the times of Indira Gandhi or her son Rajiv. The Indian political system has evolved from the system of one party domination (the Indian National Congress) to the multi-party system with the increasing participation of regional parties. Changes in the political system of India in the two last decades were accurately characterised by Douglad V. Verney: "India has arguably come a long way from being quasi-federal to quasi-confederal in the last two decades" (quoted in Nanda, 11). Another group of factors, which occurred at the same time and influenced the potential extension of the role of states in the foreign policy, are the reforms initiated in 1991 by Narashim Rao's government and his Minister of Finance, Manmohan Singh, who later became Indian Prime Minister for two terms. The influence of the reforms, which were highly liberalising and thus denationalising the economy, can be associated with development of paradiplomacy in two ways. Firstly, the introduction of New Economic Policy led to structural changes in the economy, it put an end to the domination of the

24 Previously, regional parties were of little importance in India. The Sarkaria Commission acting in India in the 1980s proved that the central government relocated, for political reasons, many state industrial factories from the state of Karnataka which was not ruled by the Indian National Congress (e.g. Indian Telephone Industries was relocated to Gonda in Uttar Pradesh) as well as exercised pressure on private investors to make them invest in other parts of India (Jha 2014, 5). 
heavy industry, limited the so called "License-Permit Raj" and first of all opened the Indian economy to the world, admitting India to the international economic circulation. Thus India departed from the centrally planned and highly centralised economy which was replaced by a model of "federal market economy". Secondly, the liberalisation of the Indian economy was associated with repealing the regulations stating that the decision on the location of economic investments lies within the competence of the federal authority. States were given the possibility of framing their own economic policy, independent of the centre. The centralisation of decisions on foreign investments location, by its very nature, led to great tensions between the centre and states as well as between different states themselves and, at the same time, also determined foreign policy. Decisions on major investments (including foreign ones), on the one hand, resulted in job creation in the region but, on the other hand, caused resettlement of a great number of citizens. Such situations were quite naturally used in the political struggle, which is typical of a democratic country. From the moment of introduction of the reforms both foreign and domestic investors can freely decide on the location of their investments. Limitation of the discretionary role of the central authorities in granting of the economic licences led to a situation where state governments can independently conduct negotiations with investors. Palaniappan Chidambaram, the former Minister of Finance in the cabinet of Manmohan Singh greatly contributed to such a positive outcome as he took the initiative to permit Chief Ministers and their Ministers of Finance to negotiate directly, without the mediation of the centre, with the government's foreign partners and investors and to sign biding contracts with them. Therefore, it must be acknowledged that the economic reforms implemented at the beginning of the 1990s are the main causative factor of the Indian paradiplomacy, which at the same time constitute its foundations. They brought about the activation of the dormant potential of free competition between states. Regions started to compete for foreign and domestic investors with unexpected energy. Until recently states such as Bihar, Madhya Pradesh, Rajasthan and Uttar Pradesh were called "Bimaru" after the first letters of their names and the word was associated with social and economic underdevelopment. However, these states believe that one of the chances to get rid of that pejorative by-name is attracting foreign investment. Thus, they compete with one another trying to facilitate the investment process as much as possible by lowering taxes or establishing special economic zones (SEZ). 
This shows that up till now the development of paradiplomacy in India has had a bottom-up character and it has been a reaction of the states to the new political and economic reality. It can be exemplified by, among others, negotiations carried out by the government of the Indian state of Maharashtra with the American Enron Corporation (1996), which no longer exists, concerning energy sale or the case of major investments by the Korean steel giant POSCO in the state of Odisha. Moreover, Indian states can also participate in the international credit market and negotiate loans bypassing the central level. Institutions such as the World Bank, the Asian Development Bank, UNICEF or the United Nations Development Program (UNDP) carry out negotiations directly with the state partners (Matoo and Jacob 2009, 177). The 1991 reforms opened up ground for Chief Ministers of states for their visits abroad to seek potential investors. Among others the Chief Ministers of West Bengal, Odisha, Madhya Pradesh, Gujarat, Andhra Pradesh, Tamil Nadu, Maharashtra or Kerala have taken advantage of it so far. The period which started then is metaphorically referred to as the era of "flying Chief Ministers". Gujarat's Chief Minister Narendra Modi took a lead in this regard but there were also others, for example the former Chief Minister of Bihar, Nitish Kumar or the Chief Minister of Madhya Pradesh, Shivraj Singh Chauhan. When paying a visit to Pakistan in 2012, Nitish Kumar visited not only the authorities of border provinces of Sindh and Punjab but also met with President Asif Ali Zardari. In 2010 the Chief Minister of Himachal Pradesh, Prem Kumar Dhumal was invited by the Governor of California, Arnold Schwarzeneger to the Global Summit on Climate Change and in 2014 the Chief Minister of Maharashtra, Prithviraj Chavan led the delegation to the World Economic Forum in Davos. In 2011 the Chief Minister of the poorest Indian state, Bihar, visited China, where he had meetings with many regional leaders. The main subject of the talks was the engagement of Chinese partners in supporting the restoration of the places of historical value such as Bodh Gaya, Nalanda or Rajgir. Not only Indian Chief Ministers have visited foreign partners but also the partners visit the Indian state authorities. It is clearly noticeable that in the two last decades states have been trying ever harder to attract world political or business leaders. The founder of Microsoft, Bill Gates and the President of the United States, Bill Clinton visited Hyderabad, whereas the Japanese Prime Minister Yoshiro Mori and the Prime Minister of China Lee Peng visited Bangalore, the capital of the state of Karnataka, the second in the world, after the Silicon Valley, centre of the computer industry. 
Apart from heads of states also the officials responsible for the implementation of foreign policy have begun to visit Indian states. In 2011 the USA Secretary of State, Hillary Clinton visited Chennai, the capital of Tamil Nadu and in 2012 she landed in Kolkata in West Bengal on her way to Delhi. A very interesting example illustrating the potential role of states in the Indian foreign policy is the reaction of some of them to India's accession first to the GATT and then (in 1995) to the World Trade Organization (WTO). Regional governments were against signing of agreements concerning agriculture by the federal government arguing that it would have a negative impact on Indian farmers. In some cases the central government was sued by certain states. The point was that by signing agreements concerning agriculture at the central level government infringed item fourteen of the aforementioned State List - the Seventh Schedule in the Constitution which reads as follows: "Agriculture, including agricultural education and research, protection against pests and prevention of plant diseases" (Bakshi 2015, 413) which allots agricultural policy to state jurisdiction.

Another example of the region's engagement in the international arena in order to protect own interests can be Kerala's government attempts at getting permission to establish a low budget air line connecting the state with the Persian Gulf countries. Approximately 3.5 million Keralites live there. Apart from the willingness to derive profits from this connection, Kerala's government wants to facilitate contacts of emigrants with the home state. It also has to be considered that remittances from the Keralites working in the Persian Gulf are a major source of the state's income and, at the same time, one of the determinants of state's economic development.

Nirupam Bajpai and Jeffrey D. Sachs (1999) divide states into three groups depending on their attitude and reactions towards the 1991 reforms:

1. Reform-oriented states: Andhra Pradesh, Gujarat, Karnataka, Maharashtra and Tamil Nadu.

2. Intermediate Reformers: Haryana, Odisha and West Bengal.

3. Lagging Reformers: Assam, Bihar, Kerala, Madhya Pradesh, Punjab, Rajasthan and Uttar Pradesh.

Putting the above mentioned division on a map of spatial diversification of India's states activity in the international arena, great convergence can be observed, which is understandable. The states whose authorities reacted positively to the 1990s reforms and carry out policy consistent with their spirit are also, in great majority, the most visible in the international 
arena. Basically, there are two kinds of the most active regions. The first group, as it was mentioned in the beginning of the study, comprises the states with international land borders or coastal states. They engage in international relations much more distinctly than those situated in the centre of the country which do not have such a favourable location, from the point of view of economic contacts with abroad. Apart from the economic issues, regional parties are frequently used by the federal government to solve problems with the closest neighbours (Tamil Nadu, West Bengal, Jammu and Kashmir). The second group comprises rich states with extensive markets, good technical infrastructure and qualified workforce. Within these two groups it is hard to find further regularities affecting the level of advancement of paradiplomacy. Thus it depends, as it has been mentioned before, mainly on the willingness of the regional authorities to carry out this kind of policy.

\subsubsection{Border states paradiplomacy and its specificity}

As it has already been mentioned, paradiplomacy in India focuses predominantly on the economic sphere. The border states and some coastal ones, which due to historical reasons exert great influence on the relations with their overseas neighbours, do not fit the rule. They have been recurrently used by the centre to solve international regional problems. The aforementioned states themselves, often being a party in the dispute, are interested in favourable for them solutions with regard to international matters ${ }^{25}$. Since the very beginning of its independence India has had a serious conflict with Pakistan, many sensitive disputes with Bangladesh, concerning primarily the division of waters, and problems with refugees from Sri Lanka, Burma, Bhutan or Tibet. When referring to the border states, we focus on their relations with the closest neighbours of India, i.e. those countries which share common land borders with India such as China, Bhutan, Nepal, Pakistan, Bangladesh and Burma or with the countries situated in the immediate geographical vicinity - Sri Lanka and the Maldives. These countries (except for China and Burma)

25 S.K. Jain mentions several questions of an international character which occurred before 1991, when particular states had very clearly defined interests (Jain 2009): "These include the proposal concerning transfer of a part of the Berubari Union No 12 to Pakistan in 1958, transfer of 900 sq.km of the Rann of Kutch to Pakistan in 1958, the liberation of Goa (1961), the liberation of Bangladesh (1971) and Status of Tamils in Sri Lanka". 
plus Afghanistan (as of 2007) form the most important organisation for cooperation in South Asia, i.e. SAARC - The South Asian Association for Regional Cooperation. Approximately $2 / 3$ of the area and 80 percent of the population comprising the SAARC countries belong to India, which in conjunction with the economic and military potential makes this country by far the most powerful within the said regional organisation. At this point, attention should be drawn to the central location of India and the fact, that most of these countries share land or maritime borders with India, albeit they do not share any borders with one another. Therefore, it was often the case that the regional coalition parties, which ruled or were influential in the border states, had different ideas about crossborder relations than the federal government. To illustrate that, it is worth recalling the case of the authorities of Punjab, Jammu and Kashmir if it comes to the relations with Pakistan, the authorities of West Bengal in the context of the relations with Bangladesh or Tamil Nadu with Sri Lanka. It can be assumed that in the nearest future any development projects in the border regions will be undertaken and implemented with significant participation of the border states. India's relations with the immediate neighbours will influence the situation in the following states:

1. Relations with Pakistan: Gujarat, Rajasthan, Punjab, Jammu and Kashmir.

2. Relations with China: Jammu and Kashmir, Uttarakhand, Himachal Pradesh, Sikkim, Arunachal Pradesh.

3. Relations with Nepal: Bihar, Uttarakhand, Uttar Pradesh, Sikkim, West Bengal.

4. Relations with Bhutan: West Bengal, Sikkim, Arunachal Pradesh, Assam.

5. Relations with Burma: Arunachal Pradesh, Nagaland, Manipur, Mizoram.

6. Relations with Bangladesh: West Bengal, Tripura, Meghalaya, Mizoram, Assam.

7. Relations with Sri Lanka: Tamil Nadu.

The relations between the aforementioned countries and the Indian Federation often concern matters directly associated with the specific nature of the border regions, mainly with regard to historical and cultural aspects but also economic ones, such as, for example, long-standing trade exchange in border territories. It is often the case that certain kinds of cross-border relations will be perceived negatively from the point of view of the federal government, whereas from the point of view of the 
local community they will be regarded as very positive. Therefore, local/ state governments - in spite of these being sometimes illegal practices - will tolerate them. A good example to illustrate this can be cross-border smuggling activity which "provides employment" for thousands of people, stimulates regional development and, from the point of view of the local economy, can be perceived as favourable.

Moreover, it should be highlighted that the states from the northern part of India are often culturally much closer to their neighbours behind the border (Pakistan, Bangladesh or Nepal) than to the states in South India. Some of these regions (i.e. for instance Bengal or Punjab) are culturally cohesive areas which, due to the Partition carried out in 1947, were arbitrarily split by the border lines. It can be assumed that major problems in the relations between India and its neighbouring countries focus not only on the differences but perhaps, first and foremost, on the similarities between them. Culturally identical Kashmiri, Sikhs, Bengalis or Tamils live on both sides of the borders. In 1947 millions of Sikhs from the Pakistani part of Punjab moved to the Indian territory leaving behind their worship sites. Throngs of Muslims crossed the border to settle in Muslim Pakistan and certain elements of their heritage, like for instance the Taj Mahal Mausoleum or the Mongolian architecture of Delhi, are on the Indian territory. Tamils from Sri Lanka often claim that they are the heirs of the Tamil culture and not Tamils living in the Indian state of Tamil Nadu. Bengalis from the Indian Bengal still cannot come to terms with the loss of Bangladesh, where the Bengalese culture was born (Chopra 2002, 9-10).

In the light of the above considerations, two kinds of border regions can be distinguished in terms of historical determinants. The first kind encompasses those which in 1947 were divided between India and the neighbouring countries, i.e. Punjab and Bengal. In their case the central government, being afraid of speeding up military escalation of historical problems, is not that willing to open up the borders widely. However, from the point of view of these states, enhancement of cross-border contacts is highly desirable for economic reasons. The conflict of interests can be noticed here in the aversion on the part of the centre to potential escalation of conflicts. In the case of other states (inter alia Gujarat, Rajasthan, Bihar and others) the central government is willing to be more permissive. The border states, by their very nature, also participate in the fight against cross-border terrorism. A perfect example of this can be Jammu and Kashmir. It is hard to imagine the "management" of the Kashmir conflict without active participation of the regional authorities. 
If it comes to the states sharing the border with Pakistan, it is worth quoting one of the former Indian diplomats who used to work in Pakistan: "There is no dissonance between Central and State governments as far as India-Pakistan relations are concerned" (Maini 2014, 24). As it can be seen, the relations with Pakistan are the subject and guarantee, with certain simplification, of more or less stable political consensus in India. Perhaps the most important factor which influences the border states' participation in the foreign policy of India is whether a particular state is ruled by the party which at the same time is the ruling party at the federal level or at least a member of the ruling coalition or whether the state is ruled by the opposition parties. In the first case, state governments usually actively participate in the foreign policy of the federal government or at least perform advisory functions.

It is sometimes possible that extremist groups are active on both sides of the border. It is the case, for instance, in the border territory between Nepal and India, where the so called Maoists operate. Members of these groups have common cultural roots and often fight hand in hand to secure their interests. As far as India is concerned, finding a solution to this problem is a federal issue. The Constitution explicitly stipulates that the external security lies within the competence of the central government.

There are situations when the policy pursued by state governments determines the directions of the federal government policy. As it has been mentioned before, the stance of the Chief Minister of West Bengal concerning the division of the waters of the Teesta River between India (West Bengal) and Bangladesh seriously harmed the relations between these two countries. When the federal Prime Minister Manmohan Singh visited neighbouring Bangladesh in 2011 he was accompanied by the Chief Ministers of four border states, i.e. Assam, Meghalaya, Tripura and Mizoram. When on February 19, 1999 the Indian Prime Minister in office at that time, Atal B. Vajpayee inaugurated a bus connection between Delhi and Lahore in Pakistan he was accompanied by the then Chief Minister of Punjab, who represented the state which was the most interested in a new transport link. The pressure exerted by Tamil Nadu state politicians on Manmohan Singh's government significantly influenced the activity of the government concerning the relations with Sri Lanka. The Tamil party Dravida Munnetra Kazhagam (DMK), a significant coalition partner of the United Progressive Alliance (UPA), contributed to deteriorating the relations of Manmohan Singh's government with Sri Lanka, which resulted in tightening the relations between Sri Lanka and the People's Republic of 
China. As a result, the Indian Prime Minister withdrew his participation in the summit of the Commonwealth of Nations in Colombo. Moreover, in 2013 the Indian government voted against Sri Lanka in the United Nations Human Rights Commission.

The significance of smaller parties of a regional character can be also exemplified by the situation when after adopting the nuclear agreement between the United States and India (2007-2008) the communist parties, i.e. the Communist Party of India (Marxist) (CPM) and the Communist Party of India (CPI) stepped out of the governing coalition UPA (United Progressive Alliance). These parties are not regional ones in the strict meaning of the term but they play a vital role in states such as Tripura, West Bengal or Kerala. The government of Manmohan Singh remained in power only because a new partner joined the coalition - Samajwadi Party, a regional party from the most populous state of India, Uttar Pradesh. Table 2.1 presents the influence exerted by selected Chief Ministers on the foreign policy of the federal government.

Table 2.1. Indian Chief Ministers and Foreign Policy

\begin{tabular}{|l|l|l|}
\hline \multirow{5}{*}{ Chandrababu Naidu } & $\begin{array}{l}\text { Chief Minister, Andhra } \\
\text { Pradesh (1995-2004) }\end{array}$ & $\begin{array}{l}\text { Especially proactive in reaching out to } \\
\text { the U.S. in the late 1990s and early } \\
\text { 2000s. Naidu was able to promote his } \\
\text { State, especially the city of Hyderabad, } \\
\text { as an Information Technology (IT) hub. } \\
\text { President Clinton made it a point to } \\
\text { include Hyderabad in his itinerary. }\end{array}$ \\
\hline Narendra Modi & $\begin{array}{l}\text { Chief Minister, Gujarat } \\
\text { (2002-2014) and Prime } \\
\text { Minister (2014-) }\end{array}$ & $\begin{array}{l}\text { Modi showcased Gujarat through the } \\
\text { Annual Vibrant Gujarat Summit. He } \\
\text { led delegations to a number of countries } \\
\text { including China, Japan and Singapore. }\end{array}$ \\
\hline Mamata Banerjee & $\begin{array}{l}\text { Chief Minister, West } \\
\text { Bengal }\end{array}$ & $\begin{array}{l}\text { Opposed the Teesta River Water Treaty, } \\
\text { as well as the Land Border Agreement } \\
\text { with Bangladesh. }\end{array}$ \\
\hline J. Jayalalithaa & $\begin{array}{l}\text { Chief Minister, Tamil } \\
\text { Nadu }\end{array}$ & $\begin{array}{l}\text { Pressurised the central government to } \\
\text { vote against Sri Lanka at the United } \\
\text { Nations on two occasions, in 2012 and } \\
\text { 2013. }\end{array}$ \\
\hline
\end{tabular}

Source: Maini $(2014,3)$. 
When analysing the increasing role of the border states in the foreign policy of India, it should be noted that there is a positive correlation between their role and the growing number of transport links between them and their foreign partners. The north-eastern states of India enjoy quite good transport links with Burma and further with South-East Asia. The number of bus connections with Pakistan is constantly increasing, including the connections available in successive border states such as Rajasthan, Punjab or Jammu and Kashmir. Road checkpoints on the border with China are situated mainly in Sikkim, but also in Assam, Arunachal Pradesh, Uttarakhand and Himachal Pradesh. A similar trend can be observed as regards road and railway connections with Bhutan, Nepal and Bangladesh. The extension of still poorly developed land transport infrastructure will greatly contribute to enhancing the role and significance of these regions in the international policy.

To sum up, it should be stated that in the future the border states, by their very nature, will be the states whose opinion will have to be taken into consideration by every government at the federal tier.

\subsection{Case of Gujarat}

\subsubsection{The reasons for choosing Gujarat as a subject of research}

The State of Gujarat, which is located in the western part of India, has attracted the attention of both Indian and international observers for several years. There are at least two reasons for this. On the one hand, this keen interest could be explained by the unparalleled economic development of the state which is characterised by its own specificity. The term "Gujarat model of development" 26 has even been coined. On the other hand, the

26 When evaluating the economic development in the State of Gujarat economists express different opinions. Those who criticise the Gujarat model claim that it is a case of "growth without development" proving that the main problem of the state is the fact that social development indicators lag behind economic indices. One of the leading critics of the economic policy pursued by Narendra Modi in Gujarat is the Indian Nobel laureate in Economics Amartya Sen who deplores that the indices measuring the development of education and health care are very low. According to the Reserve Bank of India report of the year 2010, in the years 2005-2010 the government of Gujarat allocated only 5.1\% of its budget resources to the social sector (the all-country average amounts to $5.8 \%$ ), and in the years from 2001-2002 to 2012-2013 13.22\% of the budget was allocated 
eyes of the whole world are focused on the person who is the driving force behind Gujarat's prosperity, Narendra Modi, who has been holding the office of the Prime Minister of the federal government since 2014. It was Modi's long-standing rule in the said state that enabled him first to keep the position of the Chief Minister for several years and subsequently led him to a remarkable political success in the federal arena. The experience of Gujarat in terms of economic, social and political development is so significant that it was first appreciated by the Gujarat community, which resulted in successive re-elections of Modi in the aforementioned state, and eventually his policy was endorsed by voters from all over India, which enabled him to take office as the Prime Minister of the country. Thus, it can be expected that the particular solutions which were tested in Gujarat will be implemented at the all-India level, which has indeed been displayed in the first years of his rule. It is noticeable even with regard to the visual identification of the activity of the new government. One of the most important initiatives launched by the federal government, the national "MAKE IN INDIA" program is emblematized by the Asiatic lion, an animal which lives solely in the Gir Forest National Park in Gujarat and is the symbol of this state ${ }^{27}$. The likely implementation of the Gujarat experience in the federal arena is one of the two primary reasons for choosing Gujarat as a subject of analysis. The other reason concerns the role which Narendra Modi assigned to paradiplomacy in the development model of the state. Paradiplomatic instruments are an essential element of the conception for development of that state. Before the federal elections Modi pointed to the example of Gujarat emphasising that he was able to establish partnership relations with Canada and Japan, implying at the same time that a new role of states in foreign policy is growing in importance. Thus, each state should enjoy the possibility of establishing partnership relations with foreign parties and paradiplomacy should be one of new instruments of foreign policy, especially with regard to economic issues, i.e. attracting foreign investment. Paradiplomacy has played a key role in the development success of Gujarat.

to education (the all-country average amounted to slightly over 15\%). As far as health care is concerned, budgetary expenditure in this regard in the budget year 2000-2001 totalled 2.8\% (Gujarat was ranked as $17^{\text {th }}$ among the largest states) and in the budget year 2010-2011 - 4.2\% (7th position) (Cf. Jaffrelot 2015). A detailed assessment of the development processes in Gujarat is highly complicated and goes beyond the objectives of this study and due to this fact it will be limited to the indispensable minimum.

27 Cf. http://www.makeinindia.com (accessed 2.01.2017). 
The analysis of the economic potential of the state and of the paradiplomatic activity undertaken by its authorities presented hereinafter will cover the period when Narendra Modi exercised the office of the Chief Minister of the state (2001-2014). It was the opening up of the state to the world and high-profile campaigns promoting Gujarat abroad that became the hallmark of Modi's time in office. This politician is, as it were, coalesced with Gujarat and lives in a specific symbiosis with that state. It was Gujarat that elevated him to the uppermost echelons of power in Delhi and it was Modi who made Gujarat recognisable not only in India but also in the international arena.

\subsubsection{The economic potential of the state}

In the years 1991-1993 radical reforms were carried out in India which consisted in liberalisation and deregulation of the economy. India abandoned the model based on economic socialism which had been adopted at the birth of independence (in the 1940s). The aforementioned reforms brought about a remarkable acceleration in the economic development of the country. As regards the rate of economic growth, India is overtaken only by China. Due to that, in the mid-2010s India ranked third in the world in terms of GDP (based on purchasing power parity) after the USA and China.

The growth in the economy triggered substantial changes in the level of development of particular regions, some of them developed at a faster pace whereas others - more slowly. Due to this fact, spatial disparity in the level of economic development aggravated. The western part of the country developed at a much faster rate. The divide between India A (north-western as well as south-western states) and India B (northeastern, eastern and middle states) became more clear-cut.

Gujarat is one of the largest Indian states with an area of $196024 \mathrm{~km}^{2}$ and a population of over 60 million people. Situated in the western part of the country, it borders with Pakistan and three Indian states, i.e. ajasthan, Maghya Pradesh and Maharashtra. GDP dynamics and Net State Domestic Product of Gujarat in the years 2004/05-2013/14 (prices from the year 2004/05) amounted to $192.4 \%$ for all India and $223.8 \%$ for Gujarat, whereas when calculated per capita it totalled $169.9 \%$ for all India and $197.3 \%$ for Gujarat. The share of the state in India's GDP increased from $5.8 \%$ in the year $2004 / 05$ to $6.8 \%$ in the year $2013 / 14$. Thus, it is clearly visible that the Gujarat economy developed faster than the overall Indian 
economy and in this way its importance grew systematically28. When analysing various data of strictly economic character concerning Gujarat, it can be noted that this state is not characterised by the absolutely highest development indicators, however in most statistics it is ranked in the group of most developed and fastest developing states. When, during the federal elections in 2014, voters were asked to indicate the state which, according to them, has the highest development indicators in India, it was Gujarat that the electorate in Rajasthan, Maharashtra, Jharkhand, Uttar Pradesh and Gujarat pointed to (Jaffrelot 2015, 837). When the BJP party, led by the Chief Minister Narendra Modi, governed Gujarat, the state gained wide recognition both in India as well as in the international arena and became a key region for new investments both domestic and foreign ones. By achieving a higher economic growth rate than the average national rate Gujarat has come to emblematise the success of neoliberal economic policy in the last two decades. The conception for economic development put forward by the ruling party, sometimes referred to as "the Chinese way" consisted in attracting big capital both domestic and international one. Traditionally, since the launching of the economic reforms in the 1990s, the economic policy of Gujarat has been based on growth-oriented cooperation between capitalists and big business and the business-friendly state, including fiscal policy. On the one hand, it resulted in a relatively high growth rate but, on the other hand, it entailed low wages and limited social spending. As a result, the community of Gujarat became polarised, which culminated in communal riots in the year 2002. The cooperation between state authorities and the corporate sector reached a peak during Narendra Modi's time in office as the Chief Minister. Investors benefited from numerous tax reliefs, they could buy land faster and more cheaply than in other states. Business-friendly policy climaxed in setting up Special Economic Zones, in which workers' rights are limited to minimum (Beale and Noronha 2014/29. It should be also pointed out that the inhabitants of Gujarat are regarded by Indians as the best entrepreneurs and the term "Gujarati", which occurs both in everyday speech as well as in the academic discourse, is synonymous in India with the word "entrepreneur" (Shah 2014, 519). The objective economic position of the state and the

28 Calculated on the basis of Handbook of Statistics on the Indian Economy, Reserve Bank of India 2014-2015, and Handbook of Statistics on India States, Reserve Bank of India 2014-2015.

29 Cf. http://www.sezindia.nic.in 
perception thereof in the mind of Indians and foreigners results from interconnected, closely coordinated and parallel processes which are very consciously implemented by the state government. The former is the process of major public investment, predominantly of an infrastructural character. The ruling officials were fully aware that it is not possible to develop big industry or attract major investors without a network of good quality roads, airports, ports or water and electricity supplies. However, even such a highly developed infrastructure, which could be considered outstanding against the Indian background, will not be able to attract anybody if it has not been adequately commercialised. Therefore, the latter process, which was eagerly implemented by Modi's government, was the paradiplomatic activity of the state authorities carried out in order to attract the aforementioned investors, which positively distinguished Gujarat against the background of other Indian states. In other words, the state government started to attach great importance to promoting the state in the international arena with an intention to make Gujarat - in the perception of potential investors - an ideal place to allocate capital.

\subsubsection{Infrastructure}

As it has already been mentioned, a necessary condition to attract capital to the state was the extension of the technical infrastructure. The location of the state of Gujarat at the Arab Sea creates perfect export opportunities, especially to The Persian Gulf, African or European markets. The coast line is $1659 \mathrm{~km}$ long, which accounts for $27.6 \%$ of the total coast line of the country. In 2010/11, 24.6\% of the country's export went just through Gujarat. In 1995 the state government, as the first in the country, proclaimed independent port policy. The policy resulted in, among others, 8 times growth of the transported cargo from 25.1 million tons in 1998/99 to 205.5 million tons in 2009/10. At present there are 41 small and medium sized ports and one major port in Kandla operating in Gujarat. The situation with regard to airports is similarly advantageous. The highest number of operating airports - 16 domestic and one international are in Gujarat. Due to extension of the road infrastructure more than $97 \%$ of Gujarat roads are hard surfaced and almost $99 \%$ of villages are connected with the surroundings via all-weather roads. Most of Gujarat territory is significantly draught prone. Many infrastructural projects (including the most popular Narmada Project) are aimed at providing water supply for industrial and agricultural needs. One of the big infrastructural problems in India is power cuts, which 
scares off potential industrial investors. Gujarat prides itself on the fact that it is among only five states which are able to provide uninterrupted power supply twenty four hours a day. Due to uninterrupted power supply practically every Gujarat village has access to information via radio and television. Gujarat's e-Village scheme introduced in 2003/04 resulted in a situation where every village panchayat has access to broadband internet. This short description shows the enormous scope of the job done by the BJP government led by Narendra Modi as the Chief Minister in the area of infrastructure development and in the context of attracting domestic and foreign capital (Dholakia and Dholakia 2015a, 246-264). The words uttered by Narendra Modi in 2011 during one of the speeches are crucial: "When I started my career as the Chief Minister of Gujarat, people used to request for power supply just for dinner purposes, which showed that Gujarat was short of power supply. From there we started our journey in the power sector and now, we are the only state in the country where three-phase uninterrupted power is being supplied. Now we don't know the meaning of load shedding. In the rest of the country, if power supply is received, it becomes news. While in Gujarat news is created when there are power cuts" 30 .

\subsubsection{Structure of the economy, poverty and illiteracy rates}

When analysing the sectoral structure of Gujarat economy and its changes in time, it should be noted that the structure is typical for developing countries transforming from pre-industrial to post-industrial state. Precise data are presented in Table 2.2.

Table 2.2. Percentage of shares of the major sectors in the GSDP at 2004/05 prices

\begin{tabular}{|c|c|c|c|c|}
\hline $\begin{array}{c}\text { Triennial } \\
\text { Average }\end{array}$ & $\begin{array}{c}\text { Primary } \\
\text { Sector }\end{array}$ & $\begin{array}{c}\text { Secondary } \\
\text { Sector }\end{array}$ & $\begin{array}{c}\text { Tertiary } \\
\text { Sector }\end{array}$ & $\begin{array}{c}\text { Total } \\
\text { GSDP }\end{array}$ \\
\hline $1979-1982$ & 46.91 & 22.91 & 30.18 & 100 \\
\hline $1989-1992$ & 32.81 & 29.05 & 38.14 & 100 \\
\hline $1999-2002$ & 20.16 & 35.79 & 44.05 & 100 \\
\hline $2008-2011$ & 14.87 & 39.05 & 46.08 & 100 \\
\hline
\end{tabular}

Source: Dholakia and Dholakia (2015b, 234).

30 Cf. http://www.narendramodi.in/hi/shri-modi-speech-at-buisnessman-of-year-awardfunction-in-mumbai-2719 react-text: 296 
$80 \vdots$ Grzegorz Bywalec

There is no distinct advantage of the tertiary sector in the evolution of the Gujarat GSDP structure as it occurs in the most developed world economies. It is associated with the fact that after the reforms from the '90s mainly industrial investment flowed in Gujarat and the process still occurs nowadays. Thus, it is not the economy with distinct tertiary sector domination.

Table 2.3 shows basic statistics concerning poverty in Gujarat in relation to the all-India average. They show that during the whole period following the economic reforms in Gujarat - both in villages and in towns - fewer people lived below the poverty line than in the rest of the country.

Table 2.3. Percentage of population below poverty line (Tendulkar Methodology)

\begin{tabular}{|c|c|c|c|c|c|c|}
\hline \multirow{2}{*}{ Years } & \multicolumn{3}{|c|}{ Gujarat } & \multicolumn{3}{c|}{ All India } \\
\cline { 2 - 7 } & Rural & Urban & Total & Rural & Urban & Total \\
\hline $1993 / 94$ & 43.10 & 28.00 & 37.80 & 50.10 & 31.80 & 45.30 \\
\hline $2004 / 05$ & 39.10 & 20.10 & 31.60 & 42.00 & 25.50 & 37.20 \\
\hline $2009 / 10$ & 26.70 & 17.90 & 23.00 & 33.80 & 20.90 & 29.80 \\
\hline $2011 / 12$ & 21.54 & 10.14 & 16.63 & 25.70 & 13.70 & 21.92 \\
\hline
\end{tabular}

Source: Dholakia and Dholakia (2015b, 239).

Looking at the data presented in the table above, in the time perspective, it can be clearly seen that both in Gujarat as well as in the whole India a considerably larger percentage of the rural population live below poverty line than in the urban areas. The process of decrease in the number of people living in extreme poverty has very similar pace both at the state and all country level. It follows that, the reforms initiated by the minister of finance Manmohan Singh result in the decrease in extreme poverty in the whole country scale and the pace of changes in Gujarat does not lag behind the whole country average. It should be also highlighted that the presented poverty statistics are still objectively high. Literacy rate is a very important development index for countries coming out from extreme poverty. While in developed countries this index is no longer a determining factor due to common literacy, it can still be used in India to analyse society's educational progress.

As it can be seen in Table 2.4, the number of people who can read and write has increased over the last half century, from $31.5 \%$ to almost $80 \%$ in Gujarat and from $28.3 \%$ to $74 \%$ on the average in the whole country, which can be considered a great success. Just as in the case of poverty rates, Gujarat literacy rates are slightly better than the all India ones. 
Table 2.4. Literacy rates by gender in Gujarat and All-India, 1961 to 2011 (in \%)

\begin{tabular}{|c|c|c|c|c|c|c|}
\cline { 2 - 7 } \multicolumn{1}{c|}{} & \multicolumn{3}{c|}{ Gujarat } & \multicolumn{3}{c|}{ All India } \\
\hline Years & Persons & Males & Females & Persons & Males & Females \\
\hline 1961 & 31.5 & 42.5 & 19.7 & 28.3 & 40.4 & 15.4 \\
\hline 1971 & 37.5 & 47.6 & 25.6 & 34.5 & 46.0 & 22.0 \\
\hline 1981 & 44.9 & 56.0 & 33.2 & 43.6 & 56.4 & 29.8 \\
\hline 1991 & 61.3 & 73.1 & 48.6 & 52.2 & 64.1 & 39.3 \\
\hline 2001 & 69.1 & 79.7 & 57.8 & 64.8 & 75.8 & 54.2 \\
\hline 2011 & 79.3 & 87.2 & 70.7 & 74.0 & 82.1 & 65.5 \\
\hline
\end{tabular}

Source: Dholakia and Dholakia (2015b, 242).

\subsubsection{Foreign Direct Investment}

The primary objective of the economic policy of Gujarat is to achieve considerable economic growth by attracting foreign capital in the form of FDI. As it can be noted in Table 2.5, Gujarat ranks fifth, which means it finds itself among the leading states in terms of pulling FDI, preceded in the ranking by large and highly industrialised states such as Maharashtra, the National Capital Territory of Delhi (which is formally a union territory), Karnataka and Tamil Nadu. In the whole period of 2000-2016 the inflow of FDI to Gujarat accounted for 5\% of the global volume of foreign direct investment located on the territory of India.

When the volume of FDI is calculated per capita, Gujarat ranks fifth as well. Taking into consideration harsh climate and difficult geographic conditions (including the fact that Gujarat borders with Pakistan), the aforementioned indices should be regarded as very positive and at the same time pointing to intense activity of regional and local authorities undertaken abroad. A substantial inflow of FDI undoubtedly results from the said activity which consists in soliciting foreign investors, highlighting the benefits of investing in Gujarat etc. In this way the state increases its output, more export and import opportunities arise, employment grows. Table 2.6 presents data which are very interesting and surprising at first glance. It shows the inflow of FDI in only one year 2015 as per selected Asian countries and major cities/regions in China and India. 
$82 \quad \vdots$ Grzegorz Bywalec

Table 2.5. The share of Indian states in the inflow of FDI in the years 2000-2016 in billions USD

\begin{tabular}{|c|c|c|}
\hline States & $\begin{array}{c}\text { The share of states in the } \\
\text { global inflow of FDI to India } \\
\text { (in percentage) }\end{array}$ & $\begin{array}{c}\text { State's position in the ranking } \\
\text { in terms of FDI per capita }\end{array}$ \\
\hline Andhra Pradesh & 4 & 6 \\
\hline West Bengal & 1 & 7 \\
\hline Delhi NCT & 22 & 5 \\
\hline Gujarat & 5 & 3 \\
\hline Karnataka & 7 & 2 \\
\hline Maharashtra & 29 & 4 \\
\hline Tamil Nadu & 7 & - \\
\hline Other states & Below 1 per cent & 1 \\
\hline
\end{tabular}

Source: Compiled and partially calculated by the author of the study on the basis of: "Quarterly Fact Sheet", Fact Sheet on Foreign Direct Investment (FDI) from April 2000 to March 201631.

Table 2.6. FDI inflow in 2015 (in billions USD) - country breakdown in the Asia-Pacific region and region breakdown in China and India

\begin{tabular}{|c|c|c|c|c|c|}
\hline Countries & $\begin{array}{c}\text { Capital } \\
\text { investment } \\
\text { (in billions } \\
\text { USD) }\end{array}$ & $\begin{array}{c}\text { Country's } \\
\text { share in the } \\
\text { Asia-Pacific } \\
\text { region }\end{array}$ & $\begin{array}{c}\text { Regions in } \\
\text { China (C) } \\
\text { and India (I) }\end{array}$ & $\begin{array}{c}\text { Capital } \\
\text { investment } \\
\text { (in billions } \\
\text { USD) }\end{array}$ & $\begin{array}{c}\text { Region's } \\
\text { share in } \\
\text { FDI in } \\
\text { China and } \\
\text { India (in } \\
\text { percentage) }\end{array}$ \\
\hline 1 & 2 & 3 & 4 & 5 & 6 \\
\hline India & 63.0 & 20 & Gujarat (I) & 12.36 & 10.0 \\
\hline China & 56.6 & 18 & $\begin{array}{c}\text { Shanghai } \\
\text { Municipality } \\
\text { (C) }\end{array}$ & 10.57 & 8.6 \\
\hline Indonesia & 38.5 & 12 & Jiangsu (C) & 9.53 & 7.7 \\
\hline
\end{tabular}

31 Cf. http://dipp.nic.in/English/Publications/FDI_Statistics/2016/FDI_FactSheet_January FebruaryMarch2016.pdf 


\begin{tabular}{|c|c|c|c|c|c|}
\hline 1 & 2 & 3 & 4 & 5 & 6 \\
\hline Vietnam & 21.1 & 7 & $\begin{array}{c}\text { Maharashtra } \\
\text { (I) }\end{array}$ & 8.28 & 6.7 \\
\hline Pakistan & 18.9 & 6 & $\begin{array}{c}\text { Andhra } \\
\text { Pradesh (I) }\end{array}$ & 6.10 & 5.0 \\
\hline Australia & 15.2 & 5 & Karnataka (I) & 4.98 & 4.0 \\
\hline Malaysia & 13.4 & 4 & $\begin{array}{c}\text { Guangdong } \\
\text { (C) }\end{array}$ & 4.49 & 3.6 \\
\hline Myanmar & 10.8 & 3 & Anhui (C) & 4.03 & 3.3 \\
\hline $\begin{array}{l}\text { South } \\
\text { Korea }\end{array}$ & 8.9 & 3 & $\begin{array}{c}\text { Tianjin } \\
\text { Municipality } \\
\text { (C) }\end{array}$ & 3.27 & 2.7 \\
\hline Philippines & 8.5 & 3 & Jharkhand (I) & 3.20 & 2.6 \\
\hline Other & 65.6 & 20 & Other & 50.23 & 45.8 \\
\hline Total & 320.5 & 100 & Total & 123.05 & 100 \\
\hline
\end{tabular}

Source: THE fDi REPORT 2016.

It turns out that the Indian state of Gujarat is the region which pulled most FDI in 2015 with investment value amounting to 12.36 billion USD, which accounts for $10 \%$ of the value of all FDI in China and India. Such a big volume of investment can undoubtedly be attributed to the fact that the policy pursued by the state government in Gujarat, which is connected with redeveloping technical infrastructure and providing investors with all the possible facilities and tax reliefs as well as with remarkable promotional activity, has brought about positive effects. On the other hand, it should also be noted that China is no longer just the beneficiary of FDI but it is slowly becoming a country which invests its capital in foreign markets ${ }^{32}$.

\subsubsection{Examples of strategic paradiplomatic activities of Gujarat authorities}

In the $21^{\text {st }}$ century the phenomenon of paradiplomacy has become common practice. Activity aimed at foreign partners is carried out by regional authorities in every country, frequently at the local level. However in most cases paradiplomatic activities are not systematic and

32 Main branches of FDI include oil and gas, infrastructure, food processing industries, information technology, gems and jewellery, biotechnology, chemicals, textiles. 
well-considered. In practice they are frequently isolated and occasional, automatically transferred from similar institutions and they are not elements of particular strategy of regional authorities. In the Indian reality Gujarat is a pioneer state if it comes to international arena activity. As it has already been mentioned, in whole India - Gujarat being no exceptionparadiplomacy is limited to economic matters, i.e. mostly to promotion of a region abroad in order to create a positive image of a state as a safe, friendly place both for big business and individual tourists. The promotional activity of Gujarat authorities sets the example for the authorities of many Indian states, and Gujarat brand is recognisable not only in India but also abroad. The state has become for India a contemporary version of Gateway of India which commemorates the site of arrival to India of King George V and Queen Mary in 1911, a kind of gateway, a shop window of modern India.

\subsubsection{Vibrant Gujarat Summit as the main tool of state's paradiplomatic activity}

Since its formation on 1 May 1960 when, on a language criterion, the former state of Bombay was divided into Gujarat and Maharashtra, Gujarat authorities have established numerous institutions aimed at attracting investments, state's promotion as well as helping potential investors ${ }^{33}$. Of course, due to economic isolationism in the first years of independence, these institutions were mainly domestic market oriented. It has to be mentioned that the first in India and in entire Asia special economic zone was established in the very state of Gujarat. The Export Processing Zone in Kandla, aimed at servicing export, was established in 1965 just five years after the state's formation ${ }^{34}$. Officials from the Department of Industry were instructed to do anything they can to obtain the highest possible number of permissions for private investments in the state from the central government. The establishment of, innovative at that time, Industrial Extension Bureau (iNDEXTb) in 1977 constituted a mile stone creating the foundation for contemporary paradiplomacy in Gujarat. This institution has been the basic state's tool providing all

\footnotetext{
33 These include the Gujarat Industrial Development Corporation, the Gujarat Industrial Finacial Corporation, the Gujarat Industrial Investment Corporation, the Gujarat State Finance Corporation, Gujarat Export Corporation.

34 Currently there exists Kandla Special Economic Zone (KASEZ). Cf. http://kasez.gov.in
} 
necessary services for investors including promotion of the state abroad ${ }^{35}$. In order to secure independence from state officials and politicians the institution was financed by means which did not directly come from the state's budget. iNDEXTb branch offices have been opened in Delhi, Mumbai, Kolkata, Chennai and in South Africa (Shah 2015). At present the opening of five new iNDEXTb offices abroad is being considered 36 .

In the year 2000 the Gujarat government published a document "Industrial policy - 2000". The main objective of industrial policy was to start competing with South and East Asia countries. The document did not mention competition with other Indian regions in attracting investments. Reviewing analogous document from 2003, a new attitude towards solving development problems of the state can be observed. The preamble clearly describes new government's objectives. The government was led by the Chief Minister Narendra Modi. The objectives are presented by means of popular catchphrases and show the direction of state's policy-including a policy towards foreign partners. Industrial policy objective is: "to establish Gujarat as a front-runner State in Global competition". The preamble also highlights cultural values of the state's residents which enhance doing business: "Trade is not our business, but our nature" as well as expresses state's rulers desire: "to provide business leadership to the entire world" The catchphrases laid down in the preamble were implemented in the form of, on the one hand, complex extension of the state's infrastructure, as it has been mentioned earlier, but on the other hand - the creation of the greatest Gujarat's paradiplomatic tool - the Vibrant Gujarat Global Investors Summit. The event is organised by the Gujarat government together with the above mentioned iNDEXTb. The summit is arranged as a series of meetings mostly of business nature aimed at attracting investments to the

35 The office's website explains this in the following manner: "iNDEXTb was set up with a noble intention to function as a 'facilitating' organization to ensure smooth and hassle-free experience for a prospective investor. The same guiding principles are hidden in the name of the organization popularly known as iNDEXTb. The letters in lowercase i.e. ' $i$ ' and ' $b$ ' encompass the entire philosophy. Professional dealings with a prospective investors should not get eclipsed in pursuit of ' $\mathrm{I}$ ' or 'ego' and that is why letter $\mathrm{i}$ is small. ' $\mathrm{b}$ ' for bureaucracy, often conjured up by a prospective investor as an intimidating entity most difficult to deal with, is given a touch of humbleness by keeping it in lowercase". Cf. www.indextb.com (accessed 12.09.2016).

36 As it was found out in an interview conducted by the author with the iNDEXTb officers (1-14.07.2016), in July 2016 it was not yet known in which cities the iNDEXTb offices would be established.

37 Cf. https://www.slideshare.net/ourvibrantgujarat/industrial-policy-2003 (accessed 14.12.2016). 
state and promotion of Gujarat in the widest possible scope. Summits take place every other year in the state's capital Gandhinagara. There have been 8 summits so far since 2003. During first five summits investments of total value of 3960148010000000 Indian rupees were declared (Shah $2105,523)$. The significance of the event can be proved by the number of countries participating in it as well as by the importance of visiting guests. Gandhinagar was visited by such important foreign guests as John Kerry (the US Secretary of State), Dr Jim Yong Kim (the President of the World Bank), Osamu Suzuki (the Chairman of the Suzuki Motor Corporation) or Ban Ki Moon (the Secretary General of the United Nations), but also the most influential Indians and foreigners of Indian origin such as: Mukesh Ambani - according to FORBES magazine the richest Indian ${ }^{38}$ or Cyrus Mistry (the Chairman of the Tata Group). The latest summit took place in January 2017 and according to information on the summit's website, 2700 international delegations from over 100 countries participated in it 39 . The summit's events were broadcast by the largest world TV stations and the host was of course the sui generis father of the event, the Prime Minister of the federal government, Narendra Modi, who boosted the prestige of the event. Having changed the position of the Chief Minister to that of the Prime Minister of the federal government, this leader mentally still remains in Gujarat. Paradoxically, the Vibrant Gujarat Summit has become the shop window of not only one state but also of entire India. The summit intended as a classic tool of regional paradiplomacy, being a bridge between the state of Gujarat and the rest of the world, has become a bridge between India and the rest of the world and a symbol of great aspirations of the new economic power.

\subsubsection{The Khushboo Gujart Ki campaign}

When analysing state's activity in the international arena, a famous advertising campaign launched in 2010 promoting tourism in Gujarat called Khushboo Gujarat Ki i.e. the scent of Gujarat should be mentioned. The campaign promoting tourism was aimed at both Indian and potential foreign tourists.

Gujarat, except for some places objectively worth visiting, was not an attractive tourist destination that allures crowds of local and international tourists. The most popular tourist guide in the world - Lonely Planet - in

38 Cf. https://www.forbes.com/india-billionaires/list/\#tab:overall (accessed 19.11.2016).

39 Cf. https://vibrantgujarat.com (accessed 06.01.2017). 
its printed version does not mention any place in Gujarat worth visiting. The state authorities are very much concerned to place Gujarat on the tourist map of India on a permanent basis. The Vibrant Gujarat Summit which took place in January 2009 drew attention, among others, to Globalization of Gujarat Tourism. The Gujarat authorities finally decided to promote Gujarat as a very attractive tourist location (Dhote 2015).

A mega star of Indian cinema Amitabh Bachchan took part in the Khushboo Gujarat Ki campaign. He directly offered Chief Minister Narendra Modi his help to promote the state. The actor became a brand ambassador of Gujarat tourism and did not take any remuneration for his activity (Mahurkar 2014). The campaign promoting tourism in Gujarat was a great success. Indexes of tourist movement in the state were higher than those of the famous all India campaign called Incredible India ${ }^{40}$.

Table 2.7. The number of tourists in Gujarat in the years 2009-10/2013-14 (in millions)

\begin{tabular}{|c|c|}
\hline Years & $\begin{array}{c}\text { The number of tourists } \\
\text { (in millions) }\end{array}$ \\
\hline $2009-2010$ & 17.01 \\
\hline $2010-2011$ & 19.81 \\
\hline $2011-2012$ & 22.36 \\
\hline $2012-2013$ & 25.4 \\
\hline $2013-2014$ & 28.79 \\
\hline
\end{tabular}

Source: Compiled by the author on the basis of data available at http://www.gujarattourism. com/downloads/tourism_sector_profile.pdf (accessed 02.03.2017).

Within two years from its introduction, the campaign resulted in a $16 \%$ increase in tourist movement in Gujarat which was two times higher than the all nation one (Daily Bashkar 2013) ${ }^{41}$. The analysis of the data in Table 2.7 clearly shows that the number of tourists in Gujarat grows year by year and Gujarat will probably soon become one of the most frequently visited states in India.

40 Cf. http://indianexpress.com/article/india/latest-news/gujarat-tourism-campaign-beatingincredible-india-big-b/ (accessed 02.02.2017).

41 Cf. http://daily.bhaskar.com/news/GUJ-AHD-after-endorsing-vibrant-gujarat-amitabhbachchan-to-promote-states-tourism-campa-4313150-NOR.html (accessed 02.02.2017). 


\subsection{In lieu of conclusions}

The subject of the activity of Indian states in the international arena has hardly been examined by the researchers specialising in federalism in India. It results from the fact that this subject matter constitutes a novelty in the Indian context. Before the far-reaching reforms of the country and its economy were launched in the 1990s, this phenomenon had practically not occurred and it was difficult to examine it as a separate subject of research. Even preliminary, tentative observations indicate that it is impossible to formulate one homogeneous model of paradiplomacy for the whole country. Each region has its own specific economic, political and cultural conditions, which determine the actions carried out by state authorities in the international arena. Some governments conduct their foreign policy in an efficient and conscious manner, making it a part of the development strategies in the region. In other cases, international contacts are incidental, occasional and do not constitute a part of a comprehensive socio-economic plan. At times, states are forced to become actors in the international context due to their geopolitical situation or ethnic proximity with the inhabitants of the neighbouring countries (West Bengal-Bangladesh, Tamil Nadu-Sri Lanka). The phenomenon of paradiplomacy is very diverse both in the time and spatial perspective. For many years, as it has been mentioned, it virtually did not exist in the Indian context. It was only in the 1990s, when the Indian economy opened up to the world, the process of reducing bureaucracy in the economy started and the period of the so called "licence raj" was coming to an end, that it became clear that it is not possible to manage the international relations of the country, which will soon become the most populous in the world, solely from an office in New Delhi. In the initial stage of reforming the country, this process had a bottom-up character and constituted a way of responding by the regional authorities to the particular need. The central government did not coordinate it. It is only in recent years, when charismatic Narendra Modi has started to play a significant role in Indian politics and the federalisation of the development process has taken place, that paradiplomacy has gained in importance. The unprecedented victory of the BJP party and Narendra Modi in the 2014 elections attracted the attention of India and the whole world to Gujarat, Modi's home state in which he exercised office as the Chief Minister for many years and achieved outstanding successes. Gujarat is obviously a very unusual example of paradiplomacy in India and it would be hard to find another state which is in a similar situation. It results from a brilliant career 
of a local politician, Modi, in the domestic and international arena. The example of Gujarat shows in what way it is possible to achieve a remarkable economic success by consciously applying paradiplomatic tools as a part of development strategy. During his thirteen-year rule in Gujarat, Narendra Modi created particular instruments by means of which he could intensely, when evaluated in the Indian context, promote the state in the domestic and international arena. The extent of his involvement was so large that he himself became the hallmark or the trademark of the region. His time in office in Gujarat ended in his becoming the most effective and powerful promotional tool of his home state. It was primarily because of his accomplishments with regard to pulling FDI that Narendra Modi was nominated as the BJP party's candidate for the post of the Prime Minister of the federal government. Modi won the elections, in this way contributing to the most disastrous defeat of the Indian National Congress in the history of India. The successes of Gujarat were highlighted in the electoral campaign, which was followed by many viewers on the domestic and international arena. The state has become a role model for the future development of India and, apparently, the most recognisable region in India, in very positive terms. Each international visit or a meeting with foreign partners is connected with publishing Narendra Modi's biographical notes in which the Gujarat experience in the activity of the incumbent Prime Minister is accentuated. This charismatic leader is perceived as a grand reformer of Gujarat and the architect of ultra-modern India. While "The Gujarat model" arises much controversy among economists, environmental activists and analysts specialising in different fields, it is much appreciated by the Indian society. It can be to a large extent attributed to the BJP propaganda and the methods in which they promote the economic development, often referred to as the Gujarat miracle.

When observing the current situation in India, we cannot have any doubts with regard to the future of paradiplomacy in this country as one of development tools. On the one hand, states, in a bottom-up manner, start to effectively emulate the activities of the Gujarat authorities from the last two decades. On the other hand, the person who has been the driving force behind the most remarkable paradiplomatic successes in India, as the Prime Minister of the federal government, makes every effort, in a topdown manner, to prompt state governments to independently establish and shape their relations with the international milieu and officially declares that paradiplomacy is one of the priorities of the foreign policy of the new government. 
$90 \vdots$ Grzegorz Bywalec

\section{References}

Amitabh Matoo, Jacob Happymoon, "Republic of India." In Foreign Relations in Federal Countries, (ed.) Hans Michelmann, 168-187. Montreal: McGill-Queen's University Press, 2009.

Bajpai Nirupam, Jeffrey D. Sachs, "The Progress of Policy Reform and Variations in Performance at the Sub-National Level in India". Columbia University Academic Commons. Available at: http://hdl.handle.net/10022/AC:P:8195, (accessed March 12, 2016) (1999).

Bakshi Parvinrai Mulwantrai, The Constitution of India. Gurgaon: LexisNexis, 2015.

Beale David, Ernesto Noronha. "Indian public-sector trade unionism in an autocratic political climate: The distinctive case of Gujarat". Capital \& Class 38(3): 517-539, (2014).

BJP Manifesto. 2014. Available at: http://www.bjp.org/images/pdf_2014/full_manifesto english_07.04.2014.pdf (accessed March 26, 2016).

Bywalec Grzegorz, Reformy ekonomiczne i polityczne a rozwój gospodarczy Indii (19912012). Łódź: Łódź University Press, 2015.

Chakrabarti Shantanu, E-mail message to author. Received on December 31, 2015.

Chopra Pran, "Relations with its neighbours challenge India's federal system." Federations: 9-10, (2002).

Dholakia Archana, Ravindra Dholakia, "Policy Reform in Economic Sectors", [in:] The Making of Miracles in Indian States, (ed.) Arvind Panagariya and M. Govinda Rao, 246-264. Oxford: Oxford University Press, 2015a.

Dholakia Archana, Ravindra Dholakia, "Growth and Development in Gujarat. An Overview", [in:] The Making of Miracles in Indian States, (ed.) Arvind Panagariya and M. Govinda Rao, 227-245. Oxford: Oxford University Press, 2015b.

Dhote Tripti, "Khushboo Gujarat Ki: Branding a Fragrance. IOSR Journal of Business and Management (International Case Study Conference 2015, Mumbai, India): 27-37, (2015).

Fernandes Vivian, Modi. Making of a Prime Minister. Leadership, Governance \& Performance. Delhi, Mumbai, Hyderabad: Orient Publishing, 2014.

Handbook of Statistics on India States 2014-2015, Mumbai: Reserve Bank of India.

Handbook of Statistics on the Indian Economy 2014-2015, Mumbai: Reserve Bank of India, 2015.

Hazarika Obja Borah, "Evolving Dynamics of Federalism and Foreign Policy. Engagement of Indian States in External Affairs." Indian Foreign Affairs Journal 9(1): 33-45, (2014).

Hazarika Obja Borah, E-mail message to author. Received on January 4, 2016.

History of SEZ. Available at: http://business.mapsofindia.com/sez/history-india.html (accessed May 25, 2016).

Jaffrelot Christophe, "What 'Gujarat Model'? - Growth without Development - and with Socio-Political Polarisation". South Asia: Journal of South Asian Studies 38(4): 820-838. 2015.

Sumitra Kumar Jain, "Federalisation of Indian Foreign Policy." Paper presented at IPSA World Congress. Santiago de Chile, July 12-15 2009.

Jha Prakash Chandra, "Federalism, Regionalism and States' Paradiplomacy in India", [in:] Federalism in India: Towards a Fresh Balance of Power, (ed.) Lancy Lobo and Jayesh Shah. Delhi and Jaipur: Rawat Publication, 2014.

Kamath Madhav Vittal, Kalindi Randeri, The Man of the Moment. Narendra Modi. New Delhi: Wide Canvas, 2013. 
Khosla Madhav, Oxford India Short Introduction. The Indian Constitution. New Delhi: Oxford University Press, 2016.

Kumar Rajiv, Modi and His Challenges. New Delhi: Bloomsbury Publishing India, 2016.

Kuznetsov Aleksander, Theory and Practice of Paradiplomacy. Subnational Governments in International Affairs. London-New York: Routledge, 2015.

Mahurkar Uday, Centrestage. Inside the Narendra Modi Model of Governance. Gurgaon: Random House India, 2014.

Maini Tridivesh Singh, "Gujarat, Rajasthan and Punjab: The Need for a Border States Group". Policy Report No. 6. The Hindu Centre for Politics and Public Policy, (2014).

Mathew George, "Republic of India", [in:] Distribution of Powers and Responsibilities in Federal Countries, (ed.) Akhar Majeed, Ronald L. Watts and Donald M. Brown. London: McGill-Queen's University Press, 2006.

Mohan C. Raja, Modi's World. Expanding India's Sphere of Influence. Noida: Harper Collins Publishers India, 2015.

Nag Kingshuk, The NaMo Story. A Political Life. New Delhi: Lotus Collection, 2014.

Nanda Prakash, "Federalisation Of Indian Foreign Policy." Occasional Paper Series 13 (Forum of Federations). Available at: http://www.forumfed.org/wp-content/uploads/ 2016/02/op13.pdf (accessed January 3, 2016).

P. M. Modi's Foreign Policy Objectives. VISION IAS. Available at: http://ajayvision.com/ beta/sites/all/themes/momentum/files/CA_Important_Issues/PM\%20Modi's\%20 Foreign\%20Policy\%20Objectives.pdf (accessed January 20, 2016).

Pankaj Kumar, Namo Mantra of Narendra Modi. New Delhi: Diamond Books, 2015.

Ratna Tanvi, "Paradiplomacy: 'A New Way for Indian Foreign Policy?'” The Diplomat November 10. Available at: http://thediplomat.com/2013/11/paradiplomacy-a-newway-for-indian-foreign-policy/ (accessed July 22, 2016), 2013.

Sanghavi Nagindas, Narendra Modi. A Political Journey. Rajkot: Wonderland Publications, 2015.

Shah Ghanshyam, "Governance of Gujarat. Good Governance for Whom and for What?, [in:] Growth or Development. Which Way is Gujarat Going, (ed.) Indira Hirway, Amita Shah and Ghanshyam Shah, 517-556. New Delhi: Oxford University Press, 2014.

Shekhar Shashi, "Narandra Modi's foreign policy vision". Available at: http://www. niticentral.com/2013/10/18/narendra-modis-foreign-policy-vision-147714.html (accessed January 2, 2016), 2013.

Staniland Paul, Vipin Narang, "State and Politics", [in:] The Oxford Handbook of Indian Foreign Policy, (ed.) David M. Malone, C. Raja Mohan, and Srinath Raghavan. Oxford: Oxford University Press, 2015.

Tavares Rodrigo, Paradiplomacy. Cities and States as Global Players. New York: Oxford University Press, 2016.

THE fDi REPORT 2016. Global greenfield investment trends. fDi intelligence. 2016. Available at: http://forms.fdiintelligence.com/report2016/files/The_fDi_Report_ 2016.pdf (accessed September 10, 2016).

Vashisht Deepa, D.G. Saxena, India@Chanakya-Modi. New Delhi: Orange Books International, 2014.

Verma Sudesh, Narendra Modi. The GameChanger. New Delhi: Vitasta Publishing, 2015. 
$92 \quad \vdots \quad$ Grzegorz Bywalec

\section{Internet sites}

https://business.mapsofindia.com

http://dipp.nic.in

http://kasez.gov.in

http://sezindia.org

http://www.gujarattourism.com/

http://www.indextb.com

http://www.makeinindia.com

https://vibrantgujarat.com

https://www.forbes.com/india-billionaires/list/\#tab:overall

https://www.slideshare.net/ourvibrantgujarat/industrial-policy-2003 